\title{
Self-aggregated dinuclear lanthanide(III) complexes as potential bimodal probes for magnetic resonance and optical imaging ${ }^{i}$
}

\author{
Martín Regueiro-Figueroa $^{\mathrm{a}}$, Aline Nonat ${ }^{\mathrm{b}}$, Gabriele A. Rolla ${ }^{\mathrm{c}}$, David Esteban-Gómez ${ }^{\mathrm{a}}$, $\underline{\text { Andrés de }}^{\mathrm{B}}$ \\ ${\underline{\text { Blas }^{a}}}^{\mathrm{a}}, \underline{\text { Teresa Rodríguez-Blas }}{ }^{\mathrm{a}}$, Loïc J. Charbonnière ${ }^{\mathrm{b} *}$, Mauro Botta ${ }^{\mathrm{c}}, \underline{\text { Carlos Platas-Iglesias }}^{\mathrm{a} \dagger}$ \\ ${ }^{a}$ Departamento de Química Fundamental, Universidade da Coruña, Campus da Zapateira, Rúa da Fraga 10, 15008 \\ A Coruña (Spain) \\ b Laboratoire d'Ingénierie Moléculaire Appliquée à l'Analyse, IPHC, UMR 7178 CNRS/UdS, ECPM Bâtiment \\ R1N0, 25 rue Becquerel, 67087 Strasbourg Cedex (France) \\ c Dipartimento di Scienze e Innovazione Tecnologica, Università del Piemonte Orientale "A. Avogadro", Viale T. \\ Michel 11, 15121 Alessandria (Italy)
}

Chemistry - A European Journal, volume 19, issue 35, pages 11696-11706, 26 August 2013

Received 01 April 2013, version of record online 11 July 2013, issue online 19 August 2013

This is the peer reviewed version of the following article:

Regueiro-Figueroa, M. , Nonat, A. , Rolla, G. A., Esteban-Gómez, D. , de Blas, A., Rodríguez-Blas, T. , Charbonnière, L. J., Botta, M. and Platas-Iglesias, C. (2013), Self-Aggregated Dinuclear Lanthanide(III) Complexes as Potential Bimodal Probes for Magnetic Resonance and Optical Imaging. Chem. Eur. J., 19: 11696-11706

which has been published in final form at https://doi.org/10.1002/chem.201301231. This article may be used for non-commercial purposes in accordance with Wiley Terms and Conditions for Use of Self-Archived Versions.

\begin{abstract}
Homodinuclear lanthanide complexes ( $\mathrm{Ln}=\mathrm{La}, \mathrm{Eu}, \mathrm{Gd}, \mathrm{Tb}, \mathrm{Yb}$ and $\mathrm{Lu}$ ) derived from a bis-macrocyclic ligand featuring two 2,2',2'-(1,4,7,10-tetraazacyclododecane-1,4,7-triyl)triacetic acid chelating sites linked by a 2,6-bis(pyrazol-1-yl)pyridine spacer $\left(\mathrm{H}_{2} \mathrm{~L}^{3}\right)$ were prepared and characterized. Luminescence lifetime measurements recorded on solutions of the $\mathrm{Eu}^{\mathrm{III}}$ and $\mathrm{Tb}^{\mathrm{III}}$ complexes indicate the presence of one innersphere water molecule coordinated to each metal ion in these complexes. The overall luminescence quantum yields were determined $\left(\emptyset_{\mathrm{H}_{2} \mathrm{O}}=0.01\right.$ for $\left[\mathrm{Eu}_{2}\left(\mathrm{~L}^{3}\right)\right]$ and 0.50 for $\left[\mathrm{Tb}_{2}\left(\mathrm{~L}^{3}\right)\right]$ in $0.01 \mathrm{MTRIS} / \mathrm{HCl}, \mathrm{pH}$ 7.4; TRIS=tris(hydroxymethyl)aminomethane), pointing to an effective sensitization of the metal ion by the bispyrazolylpyridyl unit of the ligand, especially with $\mathrm{Tb}$. The nuclear magnetic relaxation dispersion (NMRD) profiles recorded for $\left[\mathrm{Gd}_{2}\left(\mathrm{~L}^{3}\right)\right]$ are characteristic of slowly tumbling systems, showing a low-field plateau and a broad maximum around $30 \mathrm{MHz}$. This suggests the occurrence of aggregation of the complexes giving rise to slowly rotating species. A similar behavior is observed for the analogous $\mathrm{Gd}^{\mathrm{III}}$ complex containing a 4,4'-dimethyl-2,2'-bipyridyl spacer $\left(\left[\mathrm{Gd}_{2}\left(\mathrm{~L}^{1}\right)\right]\right)$. The relaxivity of $\left[\mathrm{Gd}_{2}\left(\mathrm{~L}^{3}\right)\right]$ recorded at $0.5 \mathrm{~T}$ and $298 \mathrm{~K}(\mathrm{pH} 6.9)$ amounts to $13.7 \mathrm{mM}^{-1} \mathrm{~s}^{-1}$. The formation of aggregates has been confirmed by dynamic light scattering (DLS) experiments, which provided mean particle sizes of 114 and 38 $\mathrm{nm}$ for $\left[\mathrm{Gd}_{2}\left(\mathrm{~L}^{1}\right)\right]$ and $\left[\mathrm{Gd}_{2}\left(\mathrm{~L}^{3}\right)\right]$, respectively. TEM images of $\left[\mathrm{Gd}_{2}\left(\mathrm{~L}^{3}\right)\right]$ indicate the formation of nearly
\end{abstract}

\footnotetext{
*1.charbonn@unistra.fr

† carlos.platas.iglesias@udc.es
} 
spherical nanosized aggregates with a mean diameter of about $41 \mathrm{~nm}$, together with some nonspherical particles with larger size.

Keywords: europium; gadolinium; lanthanides; luminescence; magnetic resonance imaging

\section{Introduction}

Lanthanide(III) complexes with poly(aminocarboxylate) ligands are gaining increasing interest due to their successful application in different imaging modalities. For instance, luminescent lanthanide complexes present unique photophysical properties that find applications in fields such as biomedical analyses and imaging ${ }^{[1]}$ while gadolinium complexes are currently used as contrast agents in magnetic resonance imaging (MRI). ${ }^{[2,3]}$ Lanthanide(III) complexes for application in these fields require stable complexation of the metal ion with adequate ligands to prevent the release of the toxic free-metal ion. ${ }^{[4,5]}$ Poly(aminocarboxylate) ligands based on either linear or macrocyclic frameworks are often used for this purpose, while macrobicyclic ligands have also been successfully used mostly for in vitro bioanalytical applications. ${ }^{[6]}$

A current challenge in the field of molecular imaging is the design of bimodal probes that could combine the advantages of two different imaging modalities. ${ }^{[7,8]}$ For instance, bimodal probes for MRI and optical imaging are expected to couple the high sensitivity of luminescence and the high spatial resolution of MRI. ${ }^{[9]}$ A lanthanide-based bimodal probe must contain suitable chromophoric units to provide an efficient energy transfer to populate the $\mathrm{Ln}^{\mathrm{III}}$ ion excited state (antenna effect). ${ }^{[10]}$ Moreover, the ligand must provide an adequate protection of the metal ion from the environment to minimize the quenching effect of $\mathrm{O}-\mathrm{H}$ oscillators of coordinated water molecules, which provide an efficient pathway for the radiationless deactivation of the $\mathrm{Ln}^{\mathrm{III}}$-centered excited states. ${ }^{[11]}$ Additionally, stable $\mathrm{Gd}^{\mathrm{III}}$ chelates for application as MRI contrast agents should contain at least one water molecule coordinated to the metal ion that can rapidly exchange with the bulk water of the body, which imparts an efficient mechanism for the longitudinal and transverse relaxation enhancement $\left(1 / T_{1}\right.$ and $\left.1 / T_{2}\right)$ of water protons. ${ }^{[12,13]}$ The efficiency of a contrast agent in vitro is measured in terms of its relaxivity $\left(r_{1 \mathrm{p}}\right),{ }^{[14]}$ which is defined as the relaxation-rate enhancement of water protons per $\mathrm{mM}$ concentration of metal ion. Interestingly, it has been shown that certain $\mathrm{Ln}^{\mathrm{III}}$ complexes containing one or two inner-sphere water molecules present relatively high luminescence quantum yields of the $\mathrm{Ln}^{\mathrm{III}}$ centered luminescence and high relaxivities. ${ }^{[15]}$

Most of the $\mathrm{Ln}^{\mathrm{III}}$-based systems proposed as bimodal probes (MRI/optical imaging) are based on small coordination compounds, ${ }^{[15-17]}$ but an interesting alternative was found in the development of several examples of $\mathrm{Gd}^{\mathrm{III}}$-loaded nanoparticles containing organic dyes as dual probes. ${ }^{[18]}$ Nanoparticles loaded with $\mathrm{Gd}^{\mathrm{III}}$ and luminescent units provide some advantages over small complexes, as they allow to deliver a high payload of $\mathrm{Gd}^{\mathrm{III}}$ to the target tissue, thereby overcoming the intrinsic low sensitivity of MRI. Besides, dual nanoprobes responsive in MRI and optical imaging ensure identical biodistribution in the two imaging modalities.

We have recently shown that homodinuclear $\operatorname{Ln}^{\text {III }}$ complexes containing two $2,2^{\prime}, 2^{\prime \prime}-(1,4,7,10$ tetraazacyclododecane-1,4,7-triyl)triacetic acid (DO3A) units linked by 4,4'-dimethyl-2,2'-bipyridyl $\left(\left[\operatorname{Ln}_{2}\left(\mathrm{~L}^{1}\right)\right]\right.$, Scheme 1) or 6,6'-dimethyl-2,2'-bipyridyl $\left(\left[\operatorname{Ln}_{2}\left(\mathrm{~L}^{2}\right)\right]\right)$ units provide an efficient sensitization of both $\mathrm{Eu}^{\mathrm{III}}$ and $\mathrm{Tb}^{\mathrm{III}} \cdot{ }^{[19,20]}$ Additionally, the bipyridyl coordination site of $\left[\mathrm{Ln}_{2}\left(\mathrm{~L}^{1}\right)\right]$ complexes was used to introduce $\left\{\mathrm{Ru}(\mathrm{bpy})_{2}\right\}$ (bpy=2,2'-bipyridine) and $\left\{\operatorname{Re}(\mathrm{CO})_{3} \mathrm{Cl}\right\}$ moieties, leading to the formation of heterometallic $\mathrm{d}-\mathrm{f}_{2}$ complexes that provide an efficient sensitization of the NIR emission of $\mathrm{Nd}^{\mathrm{III}}$ and $\mathrm{Yb}^{\mathrm{III}}$ in aqueous solutions. We and others have also shown that the bispyrazolylpyridyl chromophore incorporated to polyaminocarboxylate ligands can act as an efficient antenna to sensitize the luminescence of different $\mathrm{Ln}^{\mathrm{III}}$ ions that emit both in the visible and NIR regions. ${ }^{[21-23]}$ Herein we report the results of a study on 
$\left[\operatorname{Ln}_{2}\left(\mathrm{~L}^{3}\right)\right]$ systems in which two DO3A units are linked by a bispyrazolylpyridyl unit. The photophysical properties of the $\mathrm{Eu}^{\mathrm{III}}$ and $\mathrm{Tb}^{\mathrm{III}}$ complexes have been investigated in detail, and luminescence lifetime measurements have been used to determine their hydration numbers. Nuclear magnetic relaxation dispersion (NMRD) investigations on the $\left[\mathrm{Gd}_{2}\left(\mathrm{~L}^{3}\right)\right]$ complex and the $\left[\mathrm{Gd}_{2}\left(\mathrm{~L}^{1}\right)\right]$ and $\left[\mathrm{Gd}_{2}\left(\mathrm{~L}^{2}\right)\right]$ analogues were performed in order to assess their ${ }^{1} \mathrm{H}$ relaxation enhancement abilities and to gain insight into the molecular parameters governing the relaxivity. The $\left[\operatorname{Gd}_{2}\left(\mathrm{~L}^{1}\right)\right]$ and $\left[\mathrm{Gd}_{2}\left(\mathrm{~L}^{3}\right)\right]$ complexes form nanosized aggregates that were characterized by dynamic light scattering (DLS) and transmission electron microscopy (TEM).<smiles>O=C(O)CN1CCN(CC(=O)O)CCN(Cc2ccnc(-c3cc(CN4CCN(CC(=O)O)CCN(CC(=O)O)CCN(CC(=O)O)CC4)ccn3)c2)CCN(CC(=O)O)CC1</smiles><smiles>O=C(O)CN1CCN(CC(=O)O)CCN(Cc2cccc(-c3cccc(CN4CCN(CC(=O)O)CCN(CC(=O)O)CCN(CC(=O)O)CC4)n3)n2)CCN(CC(=O)O)CC1</smiles><smiles>O=C(O)CN1CCN(CC(=O)O)CCN(CC(=O)O)CCN(CC(=O)O)CCN(CC(=O)O)CCN(CC(=O)O)CCN(CC(=O)O)CCN(CC(=O)O)CC1</smiles>

Scheme 1. Ligands discussed in the present work.

\section{Results and discussion}

Synthesis and characterization of the ligand $\mathrm{L}^{3}$ and the corresponding $\mathrm{Ln}^{\mathrm{III}}$ complexes

The synthetic strategy used for the preparation of $\mathrm{H}_{6} \mathrm{~L}^{3}$ and its $\mathrm{Ln}{ }^{\mathrm{III}}$ complexes is shown in Scheme 2. 2,6Bis(3-bromomethyl-1-pyrazolyl)pyridine (1) was prepared by following the published procedure. ${ }^{[23]} \mathrm{N}$ Alkylation of $\mathrm{DO} 3 \mathrm{~A}(t \mathrm{BuO})_{3}{ }^{[24]}$ with $\mathbf{1}$ in refluxing acetonitrile in the presence of $\mathrm{Na}_{2} \mathrm{CO}_{3}$ gave compound $\mathbf{2}$ in $78 \%$ yield. Full deprotection of the tert-butyl esters of $\mathbf{2}$ was cleanly achieved with a 
$\mathrm{CF}_{3} \mathrm{COOH} / \mathrm{H}_{2} \mathrm{O}$ (1:1) mixture to give the desired ligand as the hexatrifluoroacetate salt (81\% yield). Subsequent reaction of $\mathrm{H}_{6} \mathrm{~L}^{3} \cdot 6 \mathrm{CF}_{3} \mathrm{COOH} \cdot 5 \mathrm{H}_{2} \mathrm{O}$ with lanthanide triflates in the presence of an excess of triethylamine resulted in the formation of compounds of formula $\left[\mathrm{Ln}_{2}\left(\mathrm{~L}^{3}\right)\right] \cdot 2 \mathrm{H}_{2} \mathrm{O}(\mathrm{Ln}=\mathrm{La}, \mathrm{Eu}, \mathrm{Gd}, \mathrm{Tb}, \mathrm{Yb}$ or $\mathrm{Lu})$, which were isolated in excellent yields $(87-91 \%)$. The high-resolution mass spectra $\left(\mathrm{ESI}^{+}\right)$show peaks corresponding to the $\left[\operatorname{Ln}_{2}\left(\mathrm{~L}^{3}+2 \mathrm{H}\right)\right]^{2+},\left[\mathrm{Ln}_{2}\left(\mathrm{~L}^{3}+2 \mathrm{Na}\right)\right]^{2+},\left[\mathrm{Ln}_{2}\left(\mathrm{~L}^{3}+\mathrm{H}\right)\right]^{+}$or $\left[\operatorname{Ln}_{2}\left(\mathrm{~L}^{3}+\mathrm{Na}\right)\right]^{+}$entities (Figures $\mathrm{S} 1-$ S6 in the Supporting Information), which confirms the formation of the desired binuclear neutral complexes.

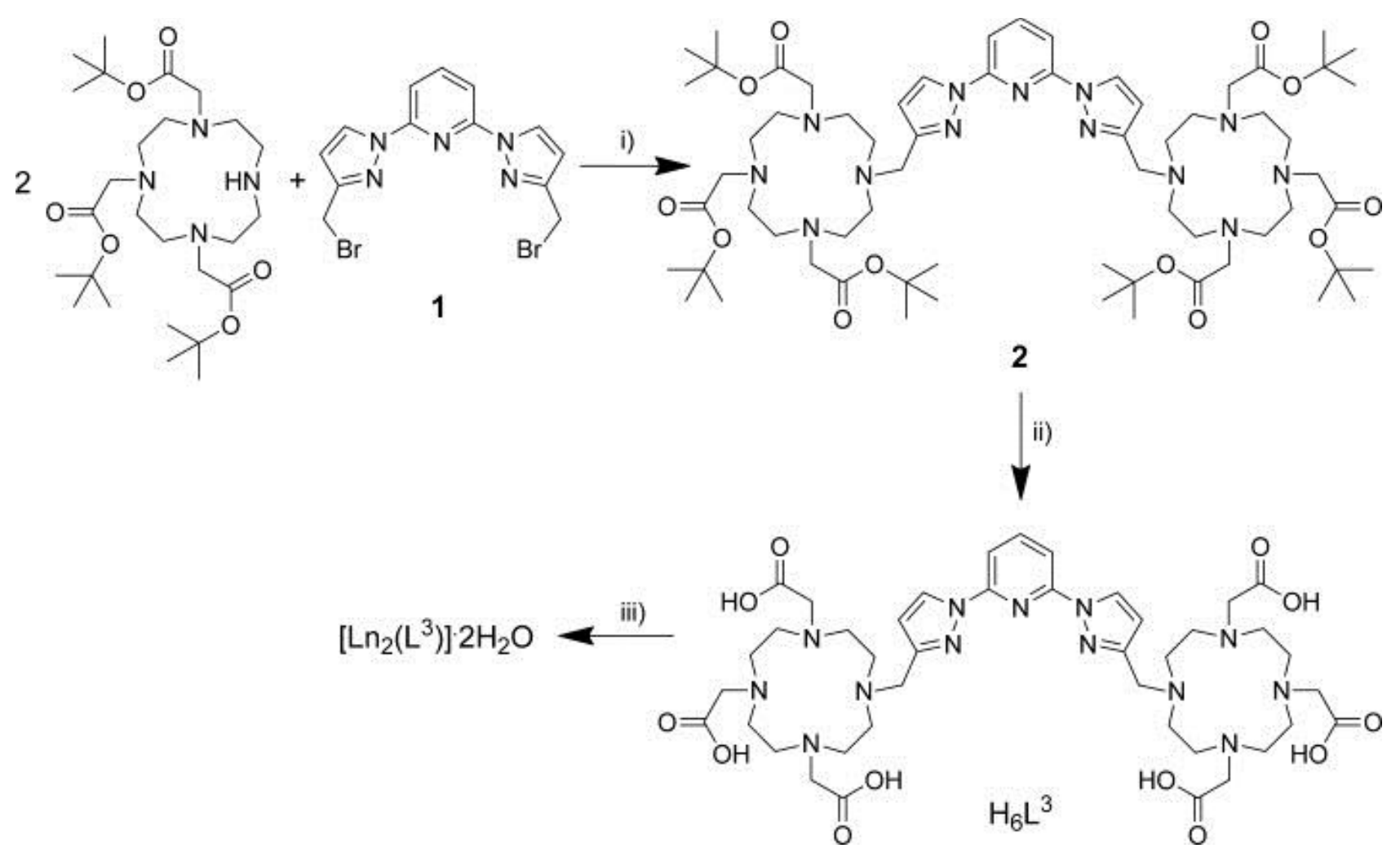

Scheme 2. i) $\mathrm{Na}_{2} \mathrm{CO}_{3}, \mathrm{CH}_{3} \mathrm{CN}, \Delta$; ii) $\mathrm{CF}_{3} \mathrm{COOH} / \mathrm{H}_{2} \mathrm{O}(1: 1), \Delta$; iii) $\mathrm{Ln}\left(\mathrm{CF}_{3} \mathrm{SO}_{3}\right)_{3}, \mathrm{Et}_{3} \mathrm{~N}$, 2-propanol, $\Delta$.

The ${ }^{1} \mathrm{H}$ spectrum of the diamagnetic $\left[\mathrm{Lu}_{2}\left(\mathrm{~L}^{3}\right)\right]$ complex recorded in $\mathrm{D}_{2} \mathrm{O}(500 \mathrm{MHz}, 298 \mathrm{~K}, \mathrm{pD} 7.0)$ shows four broad signals in the range 6.6-8.5 ppm, together with extremely broad signals in the region $2.6-4.3 \mathrm{ppm}$ typical of $\mathrm{Ln}^{\mathrm{III}}$ complexes with $N$-alkylated DO3A derivatives undergoing intramolecular dynamic exchange processes (Figure S9 in the Supporting Information) ${ }^{[25]}$ However, the presence of four signals in the aromatic region points to an effective $C_{2}$ symmetry of the complex in solution, suggesting that the two $\mathrm{Ln}^{\mathrm{III}}$ ions present identical coordination environments. A similar situation was previously observed for the complexes of $\mathrm{L}^{1},{ }^{[20]}$ in contrast to those of $\mathrm{L}^{2},{ }^{[19]}$ which present a $C_{1}$ symmetry in solution with two different coordination environments around the two $\mathrm{Ln}{ }^{\mathrm{III}}$ ions. The ${ }^{1} \mathrm{H}$ NMR spectrum of the paramagnetic $\left[\mathrm{Yb}_{2}\left(\mathrm{~L}^{3}\right)\right]$ complex (300 MHz, $298 \mathrm{~K}, \mathrm{pD}$ 7.0) also shows very broad signals due to exchange phenomena (Figure S10 in the Supporting Information). The pseudo-axial protons on the cyclen rings are observed as a very broad signal at $90 \mathrm{ppm}$. The chemical shift of this signal is characteristic of square-antiprismatic coordination geometries around the two metal ions by comparison with related compounds. ${ }^{[26]}$

Photophysical properties of the $\left[\mathrm{Ln}_{2}\left(\mathrm{~L}^{3}\right)\right]$ complexes $(\mathrm{Ln}=\mathrm{Eu}$ or $\mathrm{Tb})$

The photophysical properties of the Eu ${ }^{\mathrm{III}}$ and $\mathrm{Tb}^{\mathrm{III}}$ complexes of $\mathrm{L}^{3}$ are summarized in Table 1 . The UV/Vis absorption spectra of the $\left[\mathrm{Eu}_{2}\left(\mathrm{~L}^{3}\right)\right]$ and $\left[\mathrm{Tb}_{2}\left(\mathrm{~L}^{3}\right)\right]$ complexes in $0.01 \mathrm{M}$ TRIS-buffered aqueous solutions $(\mathrm{pH}$ 
7.4; TRIS=tris(hydroxymethyl)aminomethane) are presented in Figure 1. Both spectra display two strong absorption bands: one centered at $245 \mathrm{~nm}\left(\varepsilon=15000\right.$ and $18000 \mathrm{M}^{-1} \mathrm{~cm}^{-1}$ for $\left[\mathrm{Eu}_{2}\left(\mathrm{~L}^{3}\right)\right]$ and $\left[\mathrm{Tb}_{2}\left(\mathrm{~L}^{3}\right)\right]$, respectively), and the other at $295 \mathrm{~nm}\left(\varepsilon=9770\right.$ and $11970 \mathrm{M}^{-1} \mathrm{~cm}^{-1}$ for $\left[\mathrm{Eu}_{2}\left(\mathrm{~L}^{3}\right)\right]$ and $\left[\mathrm{Tb}_{2}\left(\mathrm{~L}^{3}\right)\right]$, respectively). Both are characteristic of $\pi \rightarrow \pi^{*}$ transitions centered on the aromatic moieties. ${ }^{[21,23]}$ Interestingly, it can be noted that the maxima of the low-energy absorption bands ( $295 \mathrm{~nm})$ correspond to a bis(pyrazolyl)pyridine system in a trans-trans conformation, as the isomerization to the cis-cis conformation results in a bathochromic shift to about $315 \mathrm{~nm} .{ }^{[21]}$ This indicates that the central pyridine nitrogen atom of the aromatic tridentate unit is not coordinated to the $\mathrm{Ln}^{\mathrm{III}}$ ion.

Table 1. Selected photophysical data for $\left[\operatorname{Ln}_{2}\left(\mathrm{~L}^{1}\right)\right],\left[\mathrm{Ln}_{2}\left(\mathrm{~L}^{2}\right)\right]$, and $\left[\mathrm{Ln}_{2}\left(\mathrm{~L}^{3}\right)\right]$ complexes $(\mathrm{Ln}=\mathrm{Eu}$ or $\mathrm{Tb})$ in aqueous solutions.

\begin{tabular}{lllllll}
\hline & $\emptyset_{\mathrm{H}_{2} \mathrm{O}}$ & $\emptyset_{\mathrm{D}_{2} \mathrm{O}}{ }^{[\mathrm{c}]}$ & $\emptyset_{\mathrm{Ln}}^{\mathrm{Ln}}$ & $\tau_{\mathrm{H}_{2} \mathrm{O}}[\mu \mathrm{s}]$ & $\tau_{\mathrm{D}_{2} \mathrm{O}}[\mu \mathrm{s}]^{[\mathrm{cc}]}$ & $q^{[\mathrm{f}]}$ \\
\hline$\left[\mathrm{Eu}_{2}\left(\mathrm{~L}^{\mathrm{l}}\right)\right]$ & $0.084^{[\mathrm{a}]}$ & - & $0.13^{[\mathrm{aa}]}$ & $560^{[\mathrm{a}]}$ & 1680 & 0.8 \\
{$\left[\mathrm{~Tb}_{2}\left(\mathrm{~L}^{1}\right)\right]$} & $0.25^{[\mathrm{a}]}$ & - & - & $1440^{[\mathrm{a}]}$ & 2540 & 1.3 \\
{$\left[\mathrm{Eu}_{2}\left(\mathrm{~L}^{2}\right)\right]$} & $0.07^{[\mathrm{b}]}$ & 0.16 & $0.16^{[\mathrm{b}]}$ & $1210^{[\mathrm{b}, \mathrm{d}]}$ & $1900^{[\mathrm{d}]}$ & $0.1^{[\mathrm{d}]}$ \\
& & & & $440^{[\mathrm{b}, \mathrm{e}]}$ & $\mathrm{ca} .1800^{[\mathrm{e}]}$ & $1.8^{[\mathrm{e}]}$ \\
{$\left[\mathrm{Tb}_{2}\left(\mathrm{~L}^{2}\right)\right]$} & $0.51^{[\mathrm{b}]}$ & 0.57 & - & $2048^{[\mathrm{b}]}$ & 3180 & 0.6 \\
{$\left[\mathrm{Eu}_{2}\left(\mathrm{~L}^{3}\right)\right]$} & $0.01^{[\mathrm{b}]}$ & 0.05 & $0.11^{[\mathrm{b}]}$ & $624^{[\mathrm{b}]}$ & 1879 & 1.0 \\
{$\left[\mathrm{~Tb}_{2}\left(\mathrm{~L}^{3}\right)\right]$} & $0.50^{[\mathrm{b}]}$ & 0.99 & - & $1858^{[\mathrm{b}]}$ & 3952 & 1.1 \\
\hline
\end{tabular}

[a] TRIS/HCl, pH 7.4, 0.1 M. [b] TRIS/HCl, pH 7.4, 0.01 M. [c] $\mathrm{D}_{2} \mathrm{O}, \mathrm{pD}$ 7.4. [d] Site I. [e] Site II.

[f] According to ref. 28. Estimated errors: $\pm 10 \%$ on lifetimes, $\pm 15 \%$ on quantum yields.

Upon excitation into the absorption band in the UV/Vis domain, the complexes display emission patterns characteristic of the ${ }^{5} \mathrm{D}_{0} \rightarrow{ }^{7} \mathrm{~F}_{\mathrm{J}}(J=0-4)$ and ${ }^{5} \mathrm{D}_{4} \rightarrow{ }^{7} \mathrm{~F}_{\mathrm{J}}(J=6-3)$ transitions of the Eu ${ }^{\text {III }}$ and $\mathrm{Tb}^{\mathrm{III}}$ ions, respectively (Figure 1) ${ }^{[27]}$ In both cases, no residual fluorescence of the ligand could be observed. Moreover, the excitation spectra recorded upon metal-centered emission are very similar to the corresponding absorption spectra, which strongly suggest an efficient ligand-to-metal energy transfer (Figure 1).

A detailed analysis of the Eu ${ }^{\text {III }}$ emission spectrum (Figure 1) reveals the presence of one sharp component centered at $579.0 \mathrm{~nm}$ corresponding to the ${ }^{5} \mathrm{D}_{0} \rightarrow{ }^{7} \mathrm{~F}_{0}$ transition, which is indicative of the presence of a single species in solution. The spectral region corresponding to the ${ }^{5} \mathrm{D}_{0} \rightarrow{ }^{7} \mathrm{~F}_{1}$ transitions displays three emission lines centered at 588.7, 591.4, and $598.0 \mathrm{~nm}$, characteristic of species with low symmetry.

The average hydration states of $\left[\mathrm{Eu}_{2}\left(\mathrm{~L}^{3}\right)\right]$ and $\left[\mathrm{Tb}_{2}\left(\mathrm{~L}^{3}\right)\right]$ were determined thanks to their luminescence lifetimes in $\mathrm{H}_{2} \mathrm{O}$ and $\mathrm{D}_{2} \mathrm{O}^{[28]}$ upon emission at 613 and $541 \mathrm{~nm}$, respectively. The emission decays could be fitted to mono-exponential decays and the corresponding lifetimes (Table 1) are in agreement with the formation of mono-hydrated species $\left(q=1.0\right.$ and 1.1 for the $\mathrm{Eu}$ and $\mathrm{Tb}$ complexes, respectively). ${ }^{[28]}$ The lifetimes measured for $\left[\mathrm{Eu}_{2}\left(\mathrm{~L}^{3}\right)\right]$ and $\left[\mathrm{Tb}_{2}\left(\mathrm{~L}^{3}\right)\right]$ are slightly longer than those previously measured for $\mathrm{L}^{1}$ analogues with the bridging methylene groups in the 4- and 4'-positions of the bipyridyl spacer. The sensitized emission quantum yields of $\left[\mathrm{Eu}_{2}\left(\mathrm{~L}^{3}\right)\right]\left(\varnothing_{\mathrm{H}_{2} \mathrm{O}}=0.01\right)$ and $\left[\mathrm{Tb}_{2}\left(\mathrm{~L}^{3}\right)\right]\left(\emptyset_{\mathrm{H}_{2} \mathrm{O}}=0.5\right)$ were determined in $0.01 \mathrm{M}$ TRIS/HCl-buffered aqueous solutions ( $\mathrm{pH} 7.4)$ by using $\left[\mathrm{Ru}(\mathrm{bpy})_{3}\right] \mathrm{Cl}_{2}\left(\emptyset_{\mathrm{H}_{2} \mathrm{O}}=0.04\right)^{[29]}$ in nondegassed water as a reference for $\mathrm{Eu}^{\mathrm{III}}$ and Rhodamine $6 \mathrm{G}\left(\varnothing_{\mathrm{H}_{2} \mathrm{O}}=0.76\right)^{[30]}$ in water for $\mathrm{Tb}^{\mathrm{III}}$. These values indicate a better emission quantum yield of the $\mathrm{Tb}^{\mathrm{III}}$ center when excited through the bispyrazolylpyridyl unit of $\mathrm{L}^{3}$ than when excited by the bipyridine chromophore of $\mathrm{L}^{1}$ substituted in the 4- and $4^{\prime}$-positions $\left(\emptyset_{\mathrm{H}_{2} \mathrm{O}}=0.25\right.$ for $\left.\left[\mathrm{Tb}_{2}\left(\mathrm{~L}^{1}\right)\right]\right)$. The overall emission quantum yields of $\left[\mathrm{Eu}_{2}\left(\mathrm{~L}^{3}\right)\right]$ and $\left[\mathrm{Tb}_{2}\left(\mathrm{~L}^{3}\right)\right]$ have also been 
measured in $\mathrm{D}_{2} \mathrm{O}$ and they amount to $\emptyset_{\mathrm{D}_{2} \mathrm{O}}=0.05$ and 0.99 , respectively. The emission quantum yield of $\left[\mathrm{Tb}_{2}\left(\mathrm{~L}^{3}\right)\right]$ is virtually identical to that determined for $\left[\mathrm{Tb}_{2}\left(\mathrm{~L}^{2}\right)\right]$, in which the bipyridyl unit coordinates to one of the $\mathrm{Tb}^{\mathrm{III}}$ ions. ${ }^{[19]}$ The quantum yields determined in $\mathrm{D}_{2} \mathrm{O}$ clearly indicate that the losses in luminescence are essentially due to quenching by water molecules in the case of $\left[\mathrm{Tb}_{2}\left(\mathrm{~L}^{3}\right)\right]$, whereas they can be in part attributed to intramolecular $\mathrm{Tb}$ to $\mathrm{Tb}$ energy transfer in the case of $\mathrm{L}^{2} \cdot{ }^{[19]}$

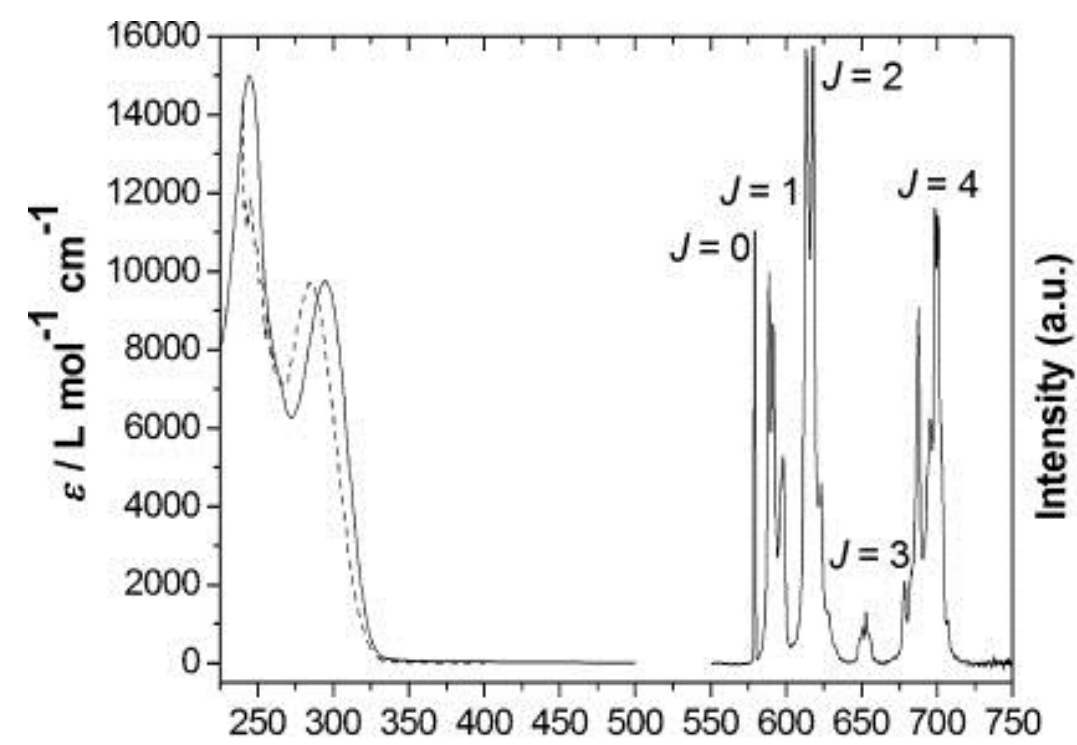

$\lambda / \mathrm{nm}$

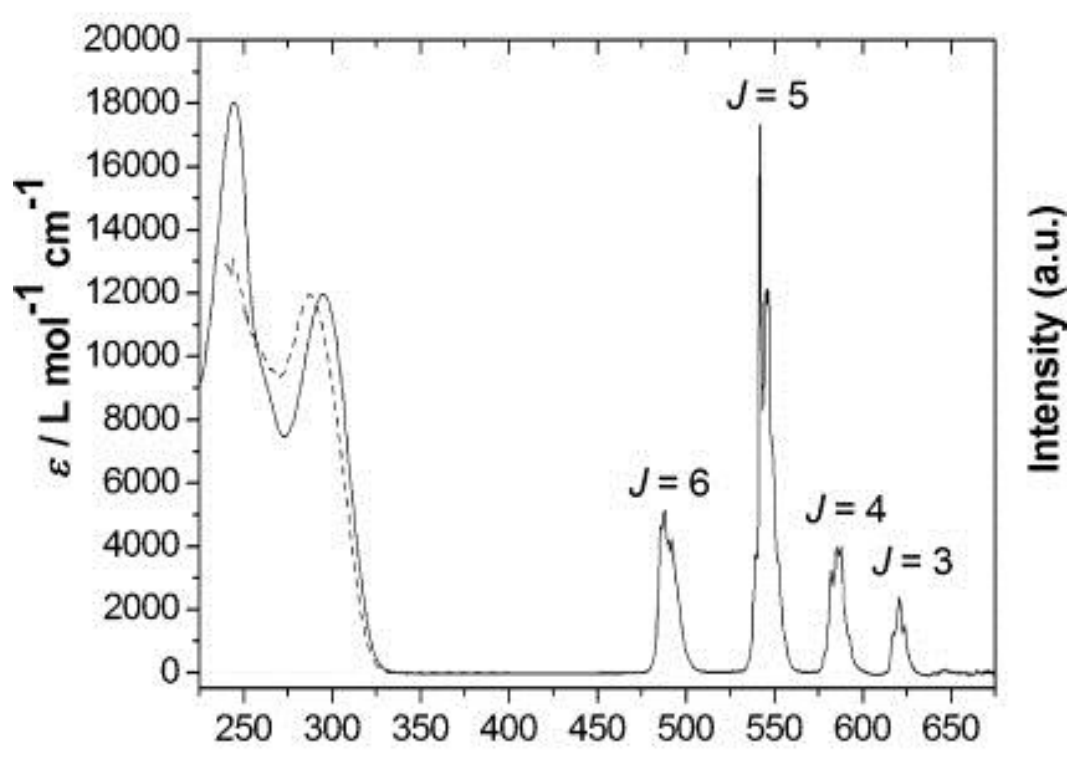

$\lambda / \mathrm{nm}$

Figure 1. UV/Vis absorption spectra, excitation spectra (dotted lines, $\mathrm{Ln}=\mathrm{Eu}, \lambda_{\mathrm{em}}=614 \mathrm{~nm} ; \mathrm{Ln}=\mathrm{Tb}, \lambda_{\mathrm{em}}=541 \mathrm{~nm}$ ) and high resolution emission spectra $\left(\lambda_{\mathrm{ex}}=287 \mathrm{~nm}\right)$ recorded for the complexes $\left[\mathrm{Eu}_{2}\left(\mathrm{~L}^{3}\right)\right]$ (top) and $\left[\mathrm{Tb}_{2}\left(\mathrm{~L}^{3}\right)\right]$ (bottom) in $0.01 \mathrm{M}$ TRIS/HCl buffered aqueous solutions $\left(\mathrm{pH} 7.4,5 \times 10^{-5} \mathrm{M}\right)$.

Relaxometric characterization of $\left[\mathrm{Gd}_{2}\left(\mathrm{~L}^{1}\right)\right],\left[\mathrm{Gd}_{2}\left(\mathrm{~L}^{2}\right)\right]$, and $\left[\mathrm{Gd}_{2}\left(\mathrm{~L}^{3}\right)\right]$ complexes

The effectiveness of a metal-based MRI probe in increasing the longitudinal relaxation rate of water protons is defined by the parameter $r_{1 \mathrm{p}}$ that, as mentioned above, describes the observed enhancement normalized to 
a one $\mathrm{mM}$ concentration of the paramagnetic ion and is dependent on temperature and applied magnetic field strength. The increase of the proton longitudinal relaxation rate of the water proton nuclei is predominantly the result of the modulation of the dipolar interaction between the electron spin of the paramagnetic metal ion and the nuclear magnetic moment of coordinated water molecules. This time modulation depends on four correlation times: the rotational correlation time $\left(\tau_{\mathrm{R}}\right)$, the longitudinal $\left(T_{1 \mathrm{e}}\right)$ and transverse $\left(T_{2 \mathrm{e}}\right)$ electron relaxation times, and the mean residence lifetime of water protons in the inner coordination sphere $\left(\tau_{\mathrm{M}}\right)$. Relaxivity also depends on the number of bound water molecules $(q)$ and their distance $\left(r_{\mathrm{Gd}-\mathrm{H}}\right)$ from the metal center. Additionally, there is a contribution to relaxivity arising from solvent molecules diffusing in the vicinity of the paramagnetic complex (outer-sphere mechanism), which depends on the relative diffusion coefficient of solute and solvent molecules $(D)$ and their distance of closest approach $(a){ }^{[2]}$

The $r_{1 \mathrm{p}}$ value of $\left[\mathrm{Gd}_{2}\left(\mathrm{~L}^{1}\right)\right]$ recorded at $0.5 \mathrm{~T}$ and $298 \mathrm{~K}$ (Figure 2) is relatively high (ca. $10.2 \mathrm{mM}^{-1} \mathrm{~s}^{-1}$ ), and remains constant over a broad $\mathrm{pH}$ range $(\mathrm{pH} 5.0-11.5)$. The relaxivity of $\left[\mathrm{Gd}_{2}\left(\mathrm{~L}^{3}\right)\right]$ recorded at $\mathrm{pH} 10.0$ is even higher $\left(13.0 \mathrm{mM}^{-1} \mathrm{~s}^{-1}\right)$, and increases slightly as the $\mathrm{pH}$ is lowered, assuming a value of 13.7 $\mathrm{mM}^{-1} \mathrm{~s}^{-1}$ at $\mathrm{pH}$ 6.9. At lower $\mathrm{pH}$ values $r_{\mathrm{lp}}$ decreases sharply due to precipitation of the complex. In the case of $\left[\mathrm{Gd}_{2}\left(\mathrm{~L}^{2}\right)\right]$ the relaxivity at $0.5 \mathrm{~T}$ and $298 \mathrm{~K}$ is considerably lower than for the corresponding complexes of $\mathrm{L}^{1}$ and $\mathrm{L}^{3}$. It assumes a value of about $7.1 \mathrm{mM}^{-1} \mathrm{~s}^{-1}$ in the $\mathrm{pH}$ range 4.4-7.9, and then decreases reaching a value of $5.4 \mathrm{mM}^{-1} \mathrm{~s}^{-1}$ at $\mathrm{pH}$ 11.5. The ${ }^{1} \mathrm{H} N \mathrm{NMR}$ spectra of the $\mathrm{Yb}^{\mathrm{III}}$ and $\mathrm{Lu}^{\mathrm{III}}$ complexes of $\mathrm{L}^{2}$ remain unchanged over the $\mathrm{pH}$ range $6-11$, which indicates that the drop in relaxivity observed for $\left[\mathrm{Gd}_{2}\left(\mathrm{~L}^{2}\right)\right]$ is not associated with a drastic change of the coordination environment of the metal ions. Interestingly, previous spectroscopic studies on the $\mathrm{Eu}$ and $\mathrm{Tb}$ complexes of $\mathrm{L}^{2}$ have shown this ligand to be the only example for which the two cations are not in the same environment. It was found that one of the two cations is fully saturated by the donor atoms of the ligand, while the second metal ion is coordinated to two water molecules. ${ }^{[19]}$ A drop of $r_{1 \mathrm{p}}$ has been observed previously for different $\mathrm{Gd}^{\mathrm{III}}$ complexes with heptadentate macrocyclic ligands, and it was attributed to the displacement of the coordinated water molecules by formation of ternary complexes with the carbonate present in the aerated aqueous solution. ${ }^{[31,32]}$

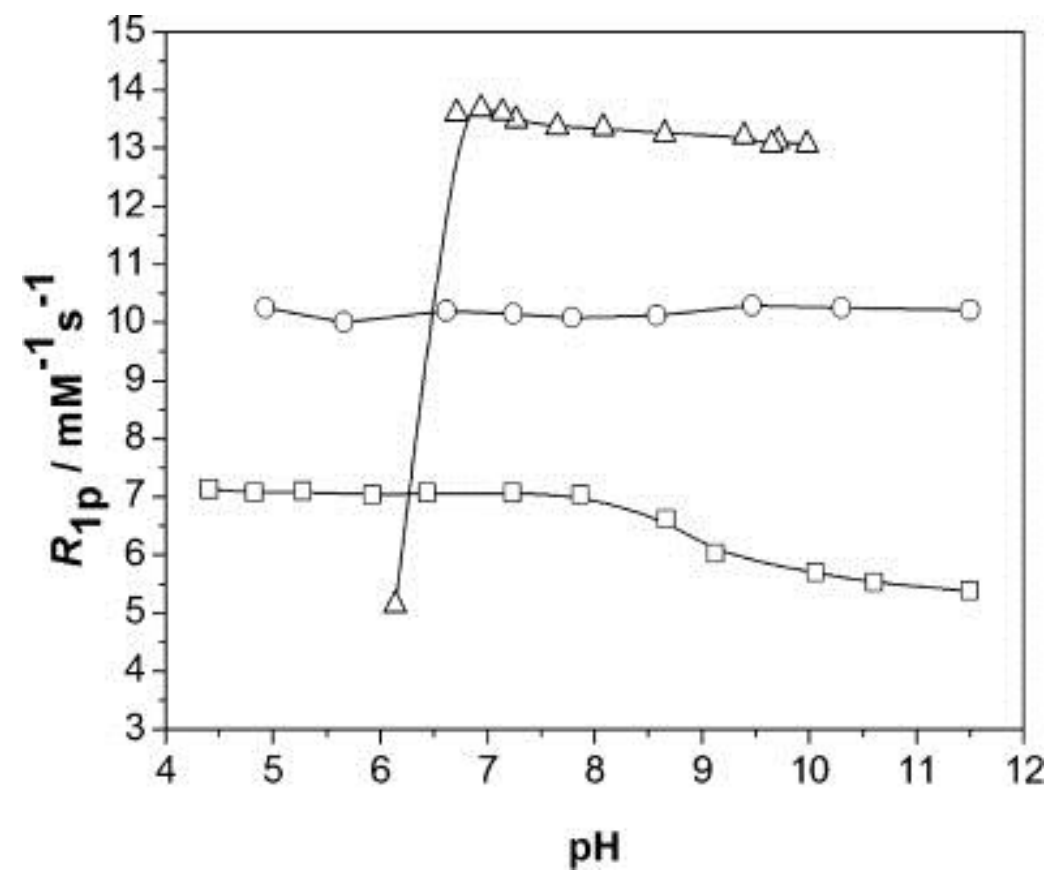

Figure 2. Plot of the relaxivity $(0.5 \mathrm{~T} ; 298 \mathrm{~K})$ of the $\mathrm{Gd}^{\mathrm{III}}$ complexes investigated in this work as a function of $\mathrm{pH}$. The solid lines are simply a guide for the eye. $\left[\mathrm{Gd}_{2}\left(\mathrm{~L}^{1}\right)\right]: \circ ;\left[\mathrm{Gd}_{2}\left(\mathrm{~L}^{2}\right)\right]: \square ;\left[\mathrm{Gd}_{2}\left(\mathrm{~L}^{3}\right)\right]: \triangle$. 

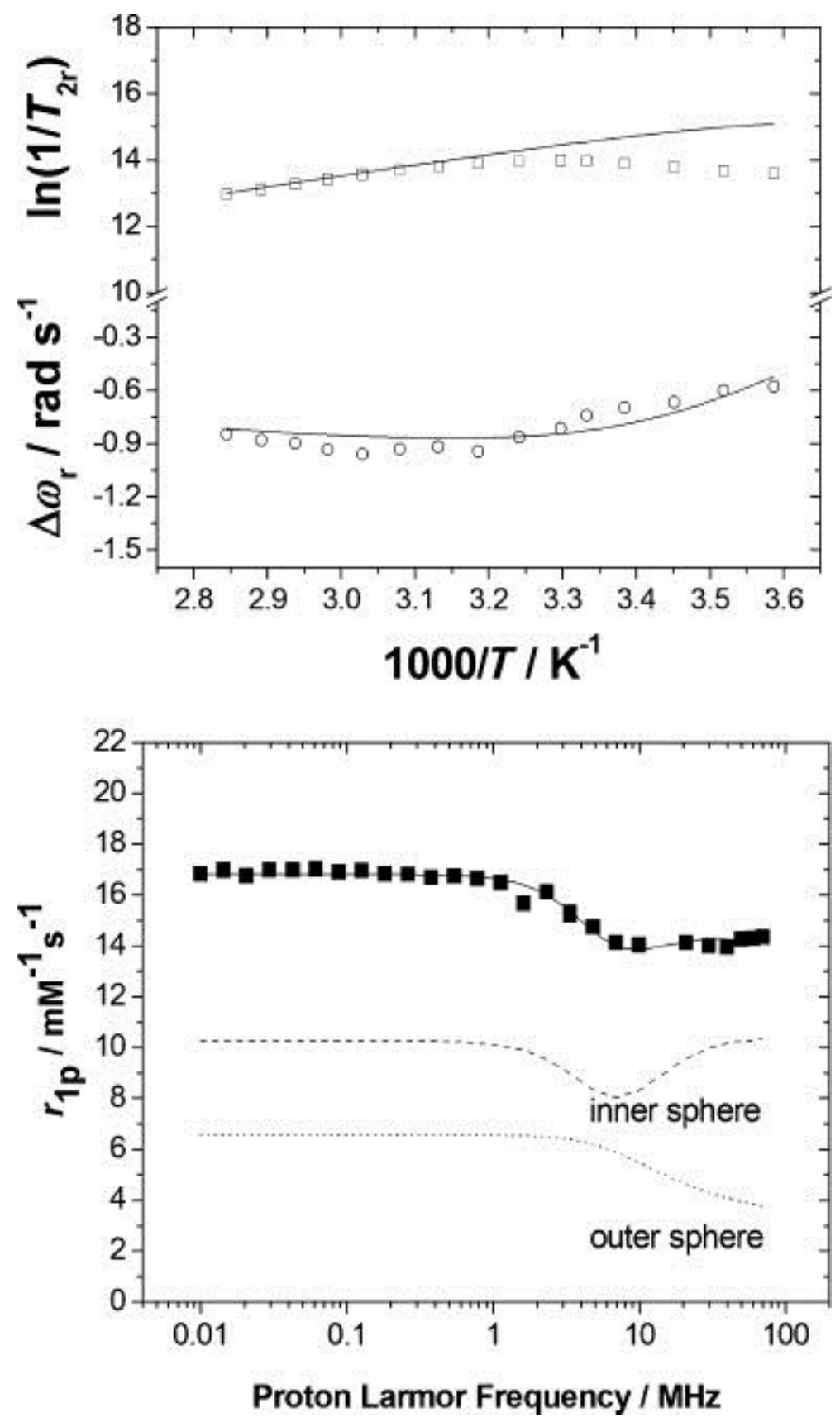

Figure 3. Top: Reduced transverse ${ }^{17} \mathrm{O}$ relaxation rates (squares) and ${ }^{17} \mathrm{O}$ chemical shifts (circles) of a $\left[\mathrm{Gd}_{2}\left(\mathrm{~L}^{2}\right)\right]$ solution $(19 \mathrm{mM})$ at $11.75 \mathrm{~T}$ and neutral $\mathrm{pH}$. Bottom: NMRD profile recorded for $\left[\mathrm{Gd}_{2}\left(\mathrm{~L}^{2}\right)\right](7.7 \mathrm{mM})$ at $298 \mathrm{~K}$ and outer- and inner-sphere contributions obtained from the analysis of the data. Relaxivities are expressed per molecule (instead of per $\mathrm{mM}$ concentration of $\mathrm{Gd}^{\mathrm{III}}$ ) due to the presence of two metal ions with different coordination environments (see text). The solid lines represent the fit of the data as described in the text.

Nuclear magnetic relaxation dispersion (NMRD) profiles of aqueous solutions of $\left[\mathrm{Gd}_{2}\left(\mathrm{~L}^{1}\right)\right],\left[\mathrm{Gd}_{2}\left(\mathrm{~L}^{2}\right)\right]$, and $\left[\mathrm{Gd}_{2}\left(\mathrm{~L}^{3}\right)\right]$ were measured at 283,298 , and $310 \mathrm{~K}$ in the proton Larmor frequency range $0.01-70 \mathrm{MHz}$, corresponding to magnetic field strengths varying between $2.343 \times 10^{-4}$ and $1.645 \mathrm{~T}$. Let us consider first the relaxometric properties of the $\left[\mathrm{Gd}_{2}\left(\mathrm{~L}^{2}\right)\right]$ complex (Figure 3). The relaxivity of $\left[\mathrm{Gd}_{2}\left(\mathrm{~L}^{2}\right)\right]$ decreases with increasing temperature (Figure S11, Supporting Information), which shows that $r_{1 \mathrm{p}}$ is limited by the fast rotation of the complex in solution, as usually observed for small, rapidly tumbling $\mathrm{Gd}^{\text {III }}$ chelates. When this occurs $\tau_{\mathrm{M}}$ cannot be determined with accuracy from the analysis of the NMRD data. Thus, we have measured ${ }^{17} \mathrm{O}$ NMR chemical shifts and transverse relaxation rates and analyzed simultaneously the ${ }^{17} \mathrm{O}$ NMR and ${ }^{1} \mathrm{H}$ NMRD data using the Solomon-Bloembergen-Morgan theory ${ }^{[33]}$ for the inner-sphere 
relaxation mechanism and the Freed model ${ }^{[34]}$ for the outer-sphere ${ }^{1} \mathrm{H}$ contribution to $r_{1 \mathrm{p}}$. However, the analysis of the ${ }^{17} \mathrm{O}$ NMR and NMRD data of $\left[\mathrm{Gd}_{2}\left(\mathrm{~L}^{2}\right)\right]$ is not straightforward due to the unique structure of this complex in solution. Indeed, the two metal coordination environments in this binuclear complex are not equivalent: one $\mathrm{Gd}^{\mathrm{III}}$ ion being coordinated by the seven donor atoms of a DO3A unit and a nitrogen atom of the bipyridyl moiety ( $q=0$, site I), while the second metal ion is bound to the second DO3A unit and two inner-sphere water molecules ( $q=1.8$ as determined for the Eu ${ }^{\mathrm{III}}$ complex, site II) ${ }^{[19]}$ Thus, the $\mathrm{Gd}^{\mathrm{III}}$ ion in site I is expected to provide only an outer-sphere contribution to $r_{1 \mathrm{p}}$, while that of site II should give rise to both inner- and outer-sphere contributions. Concerning the effect on ${ }^{17} \mathrm{O}$ NMR chemical shifts and relaxation rates, only the $\mathrm{Gd}^{\mathrm{III}}$ ion in site II is expected to be responsible for the observed effects. Further evidence for the presence of two different coordination environments with $q=0$ and $q$ approximately 2 is provided by the NMRD profiles recorded at $\mathrm{pH} 11.5$ in the presence of an excess of $\mathrm{Na}_{2} \mathrm{CO}_{3}$. Under these conditions the observed $r_{\mathrm{lp}}$ is considerably lower than that measured at neutral $\mathrm{pH}$, which is explained by the coordination of carbonate to the $\mathrm{Gd}^{\mathrm{III}}$ ion in site II. Unfortunately, the NMRD profiles measured under these conditions cannot be used directly to estimate the outer-sphere contribution to $r_{1 \mathrm{p}}$, as the coordination of a highly charged anion such as $\mathrm{CO}_{3}{ }^{2-}$ results in a substantial second-sphere contribution.

The analysis of the NMRD and ${ }^{17} \mathrm{O}$ NMR data of $\left[\mathrm{Gd}_{2}\left(\mathrm{~L}^{2}\right)\right]$ was performed under the assumption that the two $\mathrm{Gd}^{\text {III }}$ ions provide identical outer-sphere contributions to relaxivity. Satisfactory fits of the experimental NMRD curves were obtained by using the $q$ value determined from luminescence lifetime measurements on the $\mathrm{Eu}^{\mathrm{III}}$ analogue $(q=1.8$, Table 1). The distance between the proton nuclei of the coordinated water molecules and the $\mathrm{Gd}^{\mathrm{III}}$ ion was fixed to $3.1 \AA$, while the distance of closest approach between the solute and solvent molecules was taken as $4.0 \AA$. Furthermore, the coefficient that describes the relative diffusion of solute and solvent molecules $\left(D_{\mathrm{GdH}}^{298}\right)^{[35]}$ was fixed to a common value. The relevant parameters obtained from the best-fit analysis of the data profiles are compared to those of [Gd(DO3A)], [Gd(DOTA) $]^{-}$and $\left[\operatorname{Gd}_{2}\left\{\operatorname{pip}(\mathrm{DO} 3 \mathrm{~A})_{2}\right\}\right]$ in Table 2 (see Scheme 3 for the structures of the ligands). The last binuclear complex contains two DO3A units bridged by a 1,1'-(piperazine-1,4-diyl)diethanone moiety, and therefore possesses a size comparable to that of $\left[\mathrm{Gd}_{2}\left(\mathrm{~L}^{2}\right)\right]$.

Table 2. Parameters obtained from the analysis of the ${ }^{17} \mathrm{O}$ NMR and NMRD data for $\left[\mathrm{Gd}_{2}\left(\mathrm{~L}^{2}\right)\right] .{ }^{[\mathrm{a}]}$

\begin{tabular}{lllll}
\hline & {$\left[\mathrm{Gd}_{2}\left(\mathrm{~L}^{2}\right)\right]$} & {$[\mathrm{Gd}(\mathrm{DO} 3 \mathrm{~A})]^{[\mathrm{b}]}$} & {$[\mathrm{Gd}(\mathrm{DOTA})]^{[\mathrm{cc}]}$} & {$\left[\mathrm{Gd}_{2}\left\{\operatorname{pip}(\mathrm{DO} 3 \mathrm{~A})_{2}\right\}\right]^{[\mathrm{cc}]}$} \\
\hline$q$ & $\underline{1.8}$ & 1.8 & 1 & 2 \\
$k_{\mathrm{ex}}^{298}\left[10^{6} \mathrm{~s}^{-1}\right]$ & $(29.2 \pm 1.5)$ & 11 & 4.1 & 1.5 \\
$A / \hbar\left[10^{6} \mathrm{rad} \mathrm{s}^{-1}\right]$ & $(-3.9 \pm 0.8)$ & -3.9 & -3.7 & -3.8 \\
$\tau_{\mathrm{R}}^{298}[\mathrm{ps}]$ & $(185 \pm 2)$ & 103 & 77 & 171 \\
$\tau_{\mathrm{V}}^{298}[\mathrm{ps}]$ & $(35.0 \pm 1.0)$ & 27 & 11 & 19 \\
$\Delta^{2}\left[10^{20} \mathrm{~s}^{-2}\right]$ & $(0.283 \pm 0.008)$ & 0.30 & 0.16 & 0.17 \\
$D_{\mathrm{GdH}}^{298}\left[10^{-10} \mathrm{~m}^{2} \mathrm{~s}^{-1}\right]$ & $\underline{25.0}$ & - & 22 & 29 \\
$r_{\mathrm{GdH}}[\AA]$ & $\underline{3.1}$ & - & 3.1 & 3.1 \\
$a_{\mathrm{GdH}}[\AA]$ & $\underline{4.0}$ & - & 3.5 & 3.5 \\
\hline
\end{tabular}

[a] Underlined values were fixed during the fitting procedures. [b] Data from ref. 40. [c] Data from ref. 36.

Our fits provide values for the electron relaxation parameters $\tau_{\mathrm{V}}^{298}$ and $\Delta^{2}$ ) quite similar to those obtained for the DO3A and DOTA analogues. Furthermore, the ${ }^{17} \mathrm{O}$ hyperfine coupling constant of the inner-sphere water molecules $(A / \hbar)$ falls within the range generally observed for $\mathrm{Gd}^{\mathrm{III}}$ complexes $\left(-3.6 \times 10^{6} \pm 0.3\right.$ 
$\left.\operatorname{rad~s}^{-1}\right),{ }^{[37]}$ which indicates that the hydration number determined from luminescence lifetime measurements is correct $(q=1.8)$. The value of $\tau_{\mathrm{R}}^{298}$ obtained for $\left[\mathrm{Gd}_{2}\left(\mathrm{~L}^{2}\right)\right]$ is longer than those determined for mononuclear $\mathrm{Gd}^{\mathrm{III}}$ complexes, but close to those reported for different binuclear derivatives of similar molecular weight, ${ }^{[38,39]}$ including $\left[\mathrm{Gd}_{2}\left\{\operatorname{pip}(\mathrm{DO} 3 \mathrm{~A})_{2}\right\}\right] .{ }^{[36]}$ The outer-sphere contribution to relaxivity at $25^{\circ} \mathrm{C}$ (Figure 3 ) represents about $40 \%$ of the observed relaxivity in the proton Larmor frequency range $0.01-1.0 \mathrm{MHz}$, but this contribution drops to about $28 \%$ at $60 \mathrm{MHz}$.<smiles>O=C(O)CN1CCN(CC(=O)O)CCN(CC(=O)O)CCN(CC(=O)O)CCN(CC(=O)O)CCN(CC(=O)O)CCN(CC(=O)O)CCN(CC(=O)O)CCN(CC(=O)O)CCN(CC(=O)O)CCN(CC(=O)O)CCN(CC(=O)O)CCN(CC(=O)O)CC1</smiles>

Scheme 3. Ligands used for comparative purposes in Table 2.

The water exchange of the inner-sphere water molecules determined for $\left[\mathrm{Gd}_{2}\left(\mathrm{~L}^{2}\right)\right]$ is about 2.5 times faster than in $[\mathrm{Gd}(\mathrm{DO} 3 \mathrm{~A})]$ and almost 7 times faster than for $[\mathrm{Gd}(\mathrm{DOTA})]^{-}$. The water exchange of water molecules in nine-coordinate $\mathrm{Gd}^{\mathrm{III}}$ complexes proceeds through a dissociatively activated mechanism, and its rate is closely related to the steric crowding around the water-binding site. ${ }^{[41]}$ In the case of $\left[\mathrm{Gd}_{2}\left(\mathrm{~L}^{2}\right)\right]$ the presence of a bulky $[\mathrm{Gd}(\mathrm{DO} 3 \mathrm{~A})]$ unit with $q=0$ close to the nine-coordinated unit with $q=2$ might cause some steric hindrance around the coordinated water molecules. This would facilitate the departure of coordinated water molecules resulting in a fast exchange rate. The $k_{\text {ex }}$ value determined for $\left[\operatorname{Gd}_{2}\left(\mathrm{~L}^{2}\right)\right]$ $\left(29.2 \times 10^{6} \mathrm{~s}^{-1}, \tau_{\mathrm{M}}^{298}=34 \mathrm{~ns}\right)$ is close to the optimal values required to attain high relaxivities providing that $\tau_{\mathrm{R}}$ is also optimized. ${ }^{[42]}$

The NMRD profiles recorded for $\left[\mathrm{Gd}_{2}\left(\mathrm{~L}^{1}\right)\right]$ and $\left[\mathrm{Gd}_{2}\left(\mathrm{~L}^{3}\right)\right]$ show a plateau at low field $(0.01-3 \mathrm{MHz}$; Figure 4). In this region, relaxivity receives a significant contribution by the electron relaxation time. Above about 3 $\mathrm{MHz}$ the NMRD profiles of both compounds show a pronounced increase of $r_{1 \mathrm{p}}$, which reaches a maximum at about $20-30 \mathrm{MHz}$, and then decreases again at higher frequencies. Above about $3 \mathrm{MHz}$ the inner contribution to $r_{\mathrm{lp}}$ is basically determined by the residence lifetime of the inner-sphere water molecule(s) $\left(\tau_{\mathrm{M}}\right)$ and the rotational correlation time $\left(\tau_{\mathrm{R}}\right)$. The peak observed in the region $8-60 \mathrm{MHz}$, which is clearly more pronounced in the case of $\left[\mathrm{Gd}_{2}\left(\mathrm{~L}^{3}\right)\right]$, is characteristic of slowly tumbling systems with $\tau_{\mathrm{R}}$ values of the order of ns. Furthermore, the NMRD profiles of $\left[\mathrm{Gd}_{2}\left(\mathrm{~L}^{3}\right)\right]$ show reduced temperature dependence when compared to $\left[\operatorname{Gd}_{2}\left(\mathrm{~L}^{2}\right)\right]$, which indicates that both $\tau_{\mathrm{R}}$ and $\tau_{\mathrm{M}}$ are limiting $r_{1 \mathrm{p}}$ in $\left[\mathrm{Gd}_{2}\left(\mathrm{~L}^{1}\right)\right]$ and $\left[\mathrm{Gd}_{2}\left(\mathrm{~L}^{3}\right)\right]$. Thus, 
$\left[\mathrm{Gd}_{2}\left(\mathrm{~L}^{1}\right)\right]$ and $\left[\mathrm{Gd}_{2}\left(\mathrm{~L}^{3}\right)\right]$ show a nonconventional behavior that may be accounted for by self-aggregation of these complexes in aqueous solution. The longitudinal relaxation rate of aqueous solutions of $\left[\mathrm{Gd}_{2}\left(\mathrm{~L}^{3}\right)\right]$ $\left(R_{1}^{\text {obs }}\right)$ shows a linear dependence with $\mathrm{Gd}^{\mathrm{III}}$ concentration (Figure S13 in the Supporting Information) in the range $0.1-1.8 \mathrm{mM}$, which indicates that the aggregates are stable in this concentration range, with no significant disaggregation occurring.
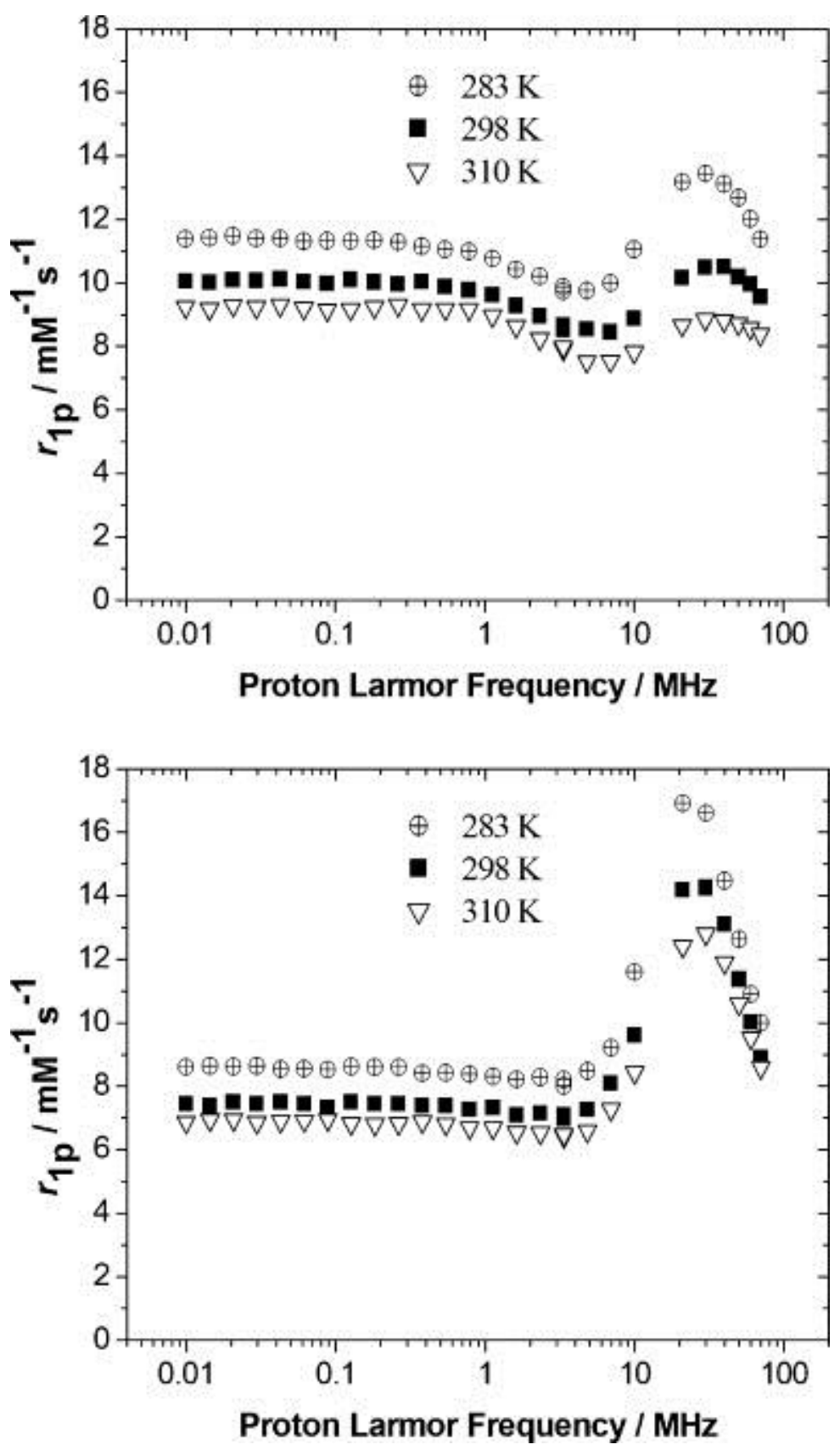

Figure 4. NMRD profiles recorded for $\left[\mathrm{Gd}_{2}\left(\mathrm{~L}^{1}\right)\right]\left(4.8 \mathrm{mM}\right.$; top) and $\left[\mathrm{Gd}_{2}\left(\mathrm{~L}^{3}\right)\right](1.7 \mathrm{mM}$; bottom) at different temperatures.

The NMRD profiles recorded for $\left[\mathrm{Gd}_{2}\left(\mathrm{~L}^{1}\right)\right]$ and $\left[\mathrm{Gd}_{2}\left(\mathrm{~L}^{3}\right)\right]$ were not analyzed to obtain rotational correlation times due to several reasons. First, the common Solomon-Bloembergen-Morgan theory cannot be used to fit NMRD profiles of slowly rotating molecules at low fields. Second, theoretical predictions show that large particles (see below) with rotational correlation times of $10 \mathrm{~ns}$ and longer should give much higher 
relaxivities (well above $40 \mathrm{mM}^{-1} \mathrm{~s}^{-1}$ ). ${ }^{[43]}$ A possible explanation for a lower relaxivity could be an important degree of flexibility of the aggregates, but this is unlikely in the case of large three-dimensional particles. Thus, the relatively low relaxivities measured for $\left[\mathrm{Gd}_{2}\left(\mathrm{~L}^{1}\right)\right]$ and $\left[\mathrm{Gd}_{2}\left(\mathrm{~L}^{3}\right)\right]$ are most likely related to the nonporous nature of the aggregates, which probably prevents the access of water molecules in proximity of the paramagnetic ions located in the interior of the particles. As a consequence, only $\mathrm{Gd}^{\mathrm{III}}$ ions at the surface of the particles contribute to relaxivity. This situation is common for Gd-based inorganic nanoparticles and it has been recently analyzed in some detail. ${ }^{[4]}$

\section{Characterization of the aggregates}

The nature of the aggregates, whose presence is suggested by the shape and amplitude of the NMRD profiles, was investigated by using different experimental techniques. In a first set of experiments, we recorded ESI-TOF mass spectra of solutions of $\left[\mathrm{Gd}_{2}\left(\mathrm{~L}^{3}\right)\right]$ in ammonium acetate buffer $(0.013 \mathrm{M}, \mathrm{pH}$ 6.7). The MS clearly show a peak at $m / z 1226.25$ corresponding to the $\left[\mathrm{Gd}_{2} \mathrm{~L}^{3}+\mathrm{CH}_{3} \mathrm{COO}\right]^{-}$entity, which is superimposed to a peak attributed to the corresponding dimer $\left[2 \mathrm{Gd}_{2} \mathrm{~L}^{3}+2 \mathrm{CH}_{3} \mathrm{COO}\right]^{2-}$ (Figure $\mathrm{S} 14$ in the Supporting Information). Very weak peaks (less than $3 \%$ of the maximum intensity) could also be observed at $m / z 1913$ and 2532, which may be attributed to $\left[3 \mathrm{Gd}_{2} \mathrm{~L}^{3}+2 \mathrm{CH}_{3} \mathrm{COO}\right]^{2-}$ and $\left[2 \mathrm{Gd}_{2} \mathrm{~L}^{3}+\mathrm{CH}_{3} \mathrm{COO}\right]^{-}$, suggesting the formation of aggregates in solution even at high dilutions $\left(<10^{-4} \mathrm{M}\right)$.

Dynamic light scattering (DLS) experiments were carried out at $298 \mathrm{~K}$ on aqueous solutions (pH 7.2) of $\left[\mathrm{Gd}_{2}\left(\mathrm{~L}^{1}\right)\right]$ and $\left[\mathrm{Gd}_{2}\left(\mathrm{~L}^{3}\right)\right]$ filtered through $450 \mathrm{~nm}$ filters. Peaks were found with a maximum corresponding to $114(0.30)$ and $38 \mathrm{~nm}\left(0.15\right.$ polydispersity index) for $\left[\mathrm{Gd}_{2}\left(\mathrm{~L}^{1}\right)\right]$ and $\left[\mathrm{Gd}_{2}\left(\mathrm{~L}^{3}\right)\right]$, respectively (Figure 5). This supports the hypothesis that these complexes tend to form relatively large aggregates in solution. In agreement with the corresponding relaxometric data, no variations were observed upon dilution of the solutions over the range $0.1-1.2 \mathrm{mM}$.

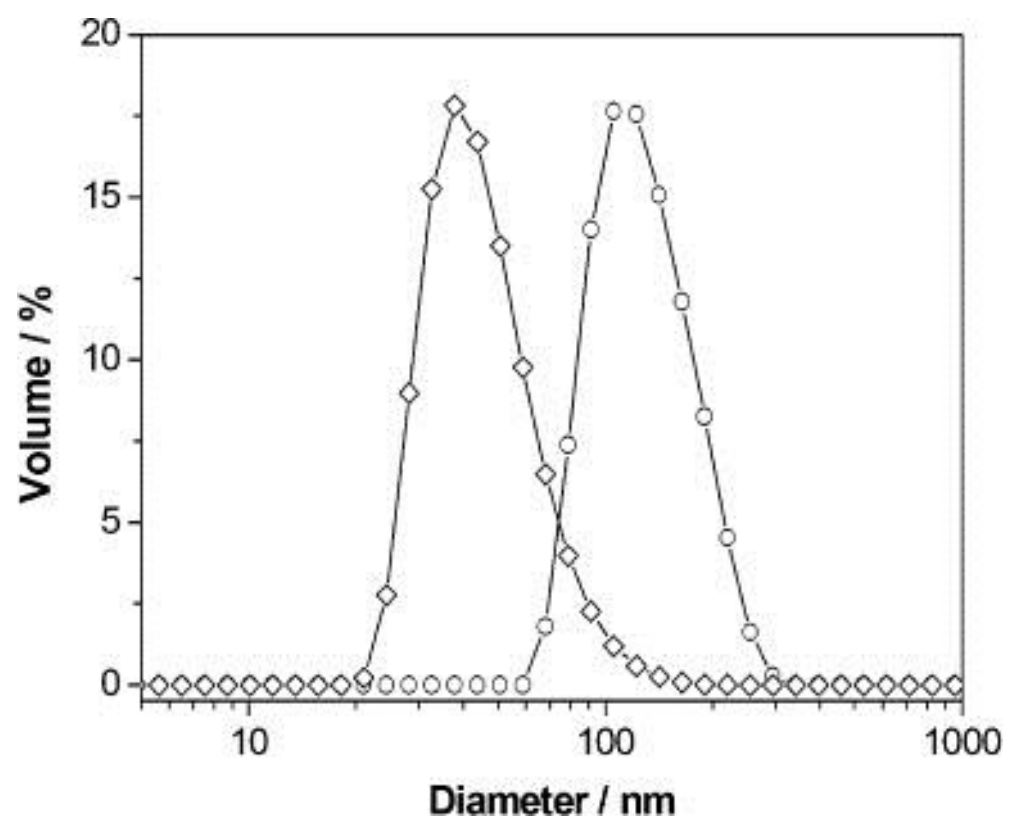

Figure 5. DLS data for $\left[\mathrm{Gd}_{2}\left(\mathrm{~L}^{1}\right)\right]$ (circles; $114 \mathrm{~nm}$ and $\left.0.15 \mathrm{PDI}\right)$ and for $\left[\mathrm{Gd}_{2}\left(\mathrm{~L}^{3}\right)\right]($ diamonds; $38 \mathrm{~nm}$ and $0.30 \mathrm{PDI})$ in aqueous solution at neutral $\mathrm{pH}(1.2 \mathrm{mM})$. The solid lines are simply a guide for the eye.

Information on the shape and size of the particles formed by $\left[\mathrm{Gd}_{2}\left(\mathrm{~L}^{3}\right)\right]$ was obtained from transmission electron microscopy (TEM) experiments (Figure 6). Most of the particles appeared to be spherical with a 
mean diameter of $41 \mathrm{~nm}$, in good agreement with the DLS data. Additionally, some larger nonspherical particles are also observed (Figure 6). The particles have a large electron density, which reflects a high Gd content.

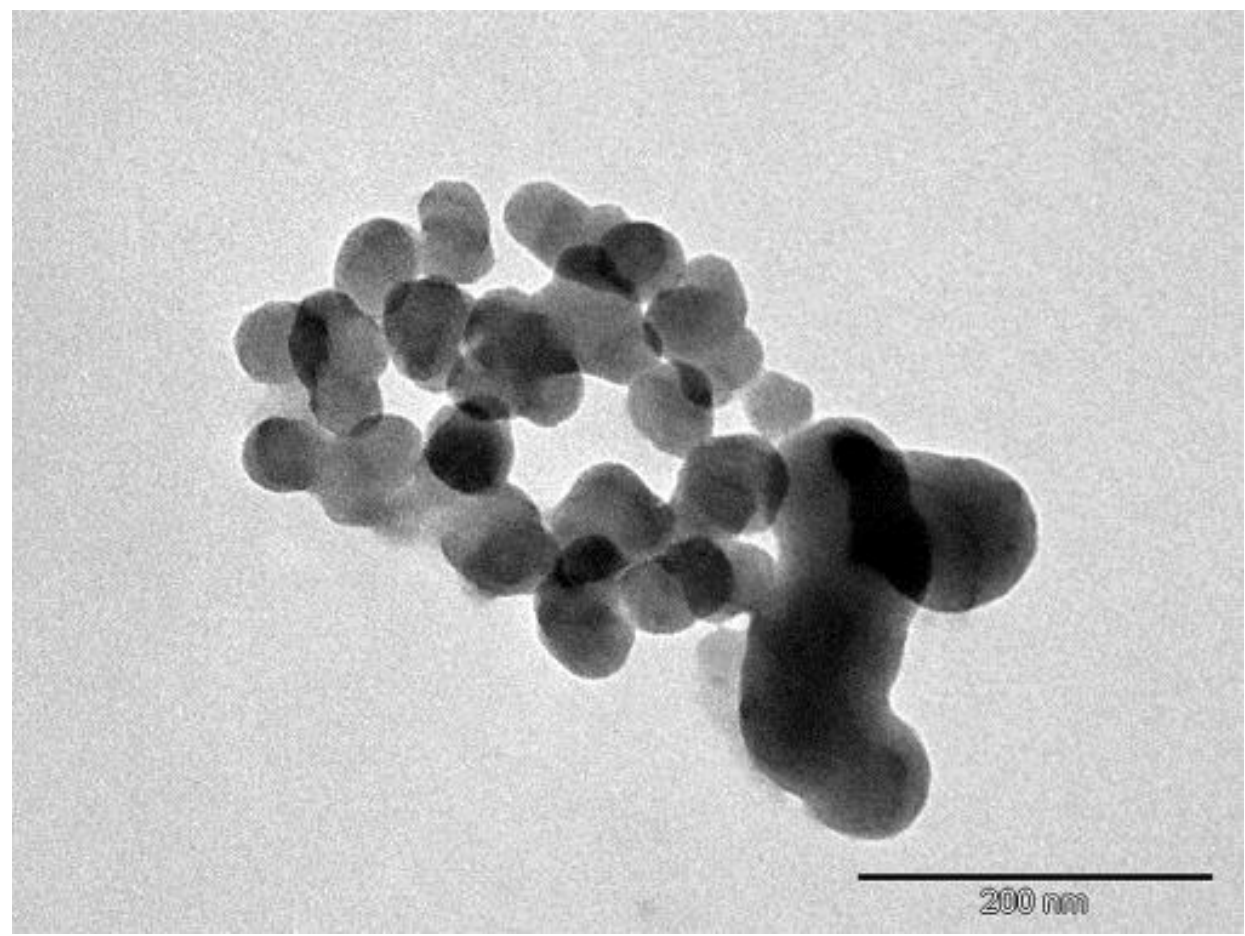

Figure 6. A typical TEM image obtained for $\left[\mathrm{Gd}_{2}\left(\mathrm{~L}^{3}\right)\right]$. Spherical particles with an average diameter of $41 \mathrm{~nm}$ are observed together with fewer nonspherical particles with larger size.

Aggregation of binuclear $\mathrm{Gd}^{\mathrm{III}}$ complexes was observed previously by using ligands that contain two DO3A units linked by a xylene core as a non-coordinating unit. ${ }^{[45]}$ The authors suggested that self-aggregation could be related to hydrophobic interactions, $\pi$ stacking between the aromatic linker, or hydrogen bonding between the chelates. A mononuclear $\mathrm{Gd}^{\mathrm{III}}$ complex with a podand bearing four 3-carboxylate pyrazole arms and a phenyl core was also shown to aggregate into spherical porous nanoparticles. ${ }^{[46]}$ In this last case the authors suggested that the formation of self-aggregates originated from weak intermolecular interactions and not from strong metal-ligand bonds inducing polymerization. We believe that in the case of $\left[\mathrm{Gd}_{2}\left(\mathrm{~L}^{1}\right)\right]$ and $\left[\mathrm{Gd}_{2}\left(\mathrm{~L}^{3}\right)\right]$ aggregation is related to the presence of bridging carboxylate units that connect neighboring binuclear entities, probably assisted by intermolecular $\pi$ stacking interactions involving the aromatic linker. There is a certain amount of evidence to support this hypothesis:

1) Different examples of lanthanide complexes forming oligomeric or polymeric units in the solid state, due to the presence of bridging bidentate carboxylate groups, have been reported in the literature. ${ }^{[47,48]}$

2) No evidence for aggregation was observed for binuclear lanthanide complexes based on two DOTA units separated by aromatic linkers. The octadentate nature of the chelating units leaves place for the coordination of a water molecule, but prevents the formation of carboxylate bridges between the two metal centers. ${ }^{[26 a, 49]}$

3) Luminescence lifetime measurements provided $q$ values of 1 , within experimental error, for the $\left[\operatorname{Ln}_{2}\left(\mathrm{~L}^{1}\right)\right]$ complexes $(\mathrm{Ln}=\mathrm{Eu}$ or $\mathrm{Tb}$, Table 1). Being DO3A derivatives, one would expect a 
hydration number closer to 2 , and therefore a low hydration number is compatible with the presence of bridging carboxylate groups. The 4,4'-dimethyl-2,2'-bipyridyl linker of $\left[\operatorname{Ln}_{2}\left(\mathrm{~L}^{1}\right)\right]$ cannot coordinate to the $\mathrm{Ln}^{\mathrm{III}}$ ion, and therefore aggregation via the formation of carboxylate bridging units is possible. In contrast, the $6,6^{\prime}$-dimethyl-2,2'-bipyridyl linker of $\left[\operatorname{Ln}_{2}\left(\mathrm{~L}^{2}\right)\right]$ complexes coordinates to the metal ion, thereby preventing aggregation.

To make a rough estimation of the number of $\left[\operatorname{Ln}_{2}\left(\mathrm{~L}^{3}\right)\right]$ units contained in a typical aggregate, we performed theoretical calculations on the $\left[\mathrm{Gd}_{2}\left(\mathrm{~L}^{3}\right)\left(\mathrm{H}_{2} \mathrm{O}\right)_{2}\right]$ system at the HF and B3LYP levels (see Computational Methods section). The minimum energy conformation obtained for $\left[\mathrm{Gd}_{2}\left(\mathrm{~L}^{3}\right)\left(\mathrm{H}_{2} \mathrm{O}\right)_{2}\right]$ shows a squareantiprismatic coordination environment around the metal ions, which are each coordinated to the four nitrogen atoms of the macrocycle, three oxygen atoms of carboxylate groups, an oxygen atom of a water molecule, and a nitrogen atom of a pyrazolyl unit. Most likely, the pyrazolyl nitrogen atom is replaced by an oxygen atom of a carboxylate group belonging to a neighboring molecule upon aggregation. The molecular volume of $\left[\mathrm{Gd}_{2}\left(\mathrm{~L}^{3}\right)\left(\mathrm{H}_{2} \mathrm{O}\right)_{2}\right]$, defined as the volume inside a contour density of $0.001 \mathrm{e} \mathrm{Bohr}^{-3}$, amounts to $1078 \AA^{3}$. Thus, considering the volume of a typical spherical particle of $38 \mathrm{~nm}$, we estimate that each particle may contain up to about $2.7 \times 10^{4}\left[\mathrm{Gd}_{2}\left(\mathrm{~L}^{3}\right)\left(\mathrm{H}_{2} \mathrm{O}\right)_{2}\right]$ units.

An important requirement of any potential bimodal probe for application in MRI and optical imaging is a high stability under physiological conditions. In the case of $\left[\mathrm{Gd}_{2}\left(\mathrm{~L}^{1}\right)\right]$ and $\left[\mathrm{Gd}_{2}\left(\mathrm{~L}^{3}\right)\right]$, the DO3A coordinating units are expected to provide enough thermodynamic and kinetic stability to the corresponding complexes. Additionally, the stability of the formed aggregates in biological media is also important. Thus, the stability with time of a $1.17 \mathrm{mMsolution}$ of $\left[\mathrm{Gd}_{2}\left(\mathrm{~L}^{3}\right)\right]$ in a lyophilized serum of human origin (Seronorm) was assessed by relaxometric measurement at $0.5 \mathrm{~T}$ and $310 \mathrm{~K}$. The complex proved to be stable at least over 96 h (Figure 7). Only very small and negligible fluctuations in the relaxation rate data were detected, well within the experimental error $( \pm 3-4 \%)$. A similar situation is observed for $\left[\operatorname{Gd}_{2}\left(\mathrm{~L}^{2}\right)\right]$, which was proved to be stable at least over $52 \mathrm{~h}$ (Figure S15 in the Supporting Information). These results thus indicate that the DO3A derivatives reported here do not experience dissociation in serum, nor particle disaggregation.

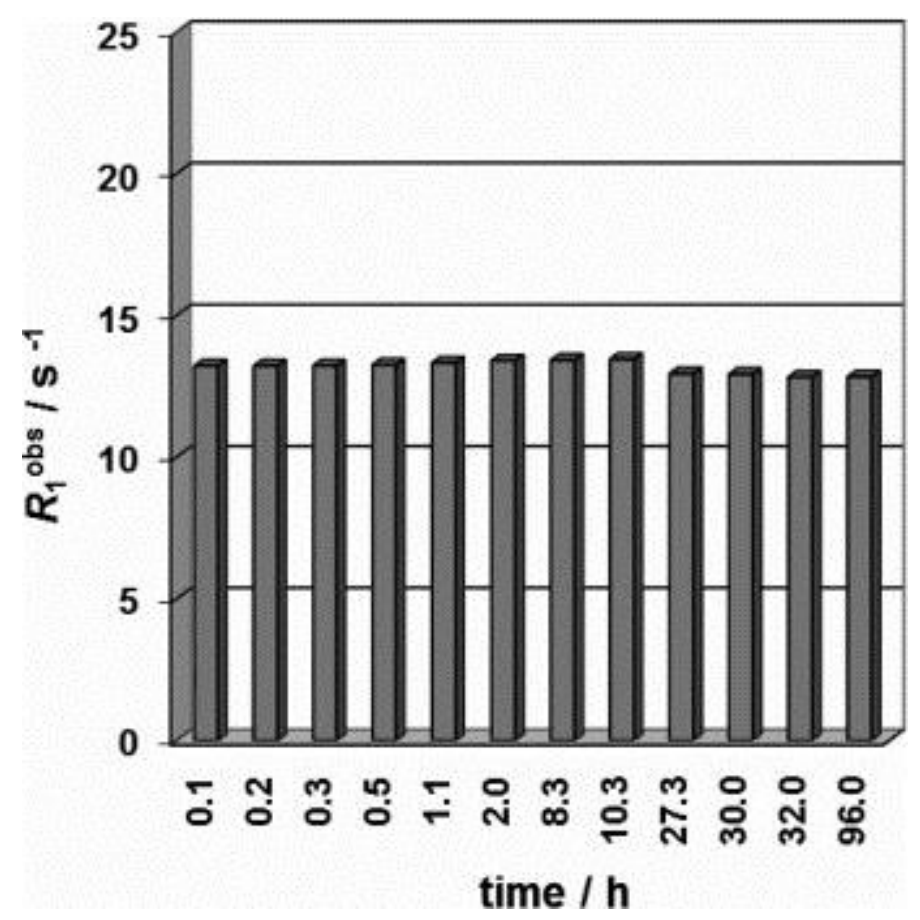

Figure 7. Proton relaxation rate at $0.5 \mathrm{~T}$ and $310 \mathrm{~K}$ of a $1.17 \mathrm{mM}$ solution of $\left[\mathrm{Gd}_{2}\left(\mathrm{~L}^{3}\right)\right]$ in Seronorm as a function of time. 


\section{Conclusion}

Binuclear $\mathrm{Ln}^{\mathrm{III}}$ complexes with bis-macrocyclic ligands $\mathrm{L}^{1}$ and $\mathrm{L}^{3}$, which contain two DO3A units linked by 4,4'-dimethyl-2,2'-bipyridine and 2,6-bis(1H-pyrazol-1-yl)pyridine spacers, respectively, form nanosized aggregates stable in aqueous solutions and serum. In contrast, the complexes of $\mathrm{L}^{2}$, which contain a $6,6^{\prime}-$ dimethyl-2,2'-bipyridyl spacer, do not aggregate probably due to the coordination of the bipyridyl moiety to one of the $\mathrm{Ln}{ }^{\mathrm{III}}$ ions. As a result, the $\left[\mathrm{Gd}_{2}\left(\mathrm{~L}^{1}\right)\right]$ and $\left[\mathrm{Gd}_{2}\left(\mathrm{~L}^{3}\right)\right]$ complexes have high relaxivities, the NMRD profiles showing a characteristic pronounced increase of $r_{1 \mathrm{p}}$ above $3 \mathrm{MHz}$ that reaches a maximum at about 20-30 MHz. The $\left[\mathrm{Gd}_{2}\left(\mathrm{~L}^{2}\right)\right]$ complex, however, provides NMRD profiles characteristic of rapidly tumbling complexes, relaxivity being limited by the fast rotation of the complex in solution. Interestingly, the simultaneous analysis of the NMRD and ${ }^{17} \mathrm{O}$ NMR data of $\left[\mathrm{Gd}_{2}\left(\mathrm{~L}^{2}\right)\right]$ indicates a relatively fast water exchange of the inner-sphere water molecules $\left(k_{e x}^{298}=29.2 \times 10^{6} \mathrm{~s}^{-1}\right)$.

Besides quite high relaxivities, the $\left[\operatorname{Ln}_{2}\left(\mathrm{~L}^{1}\right)\right]$ and $\left[\operatorname{Ln}_{2}\left(\mathrm{~L}^{3}\right)\right](\mathrm{Ln}=\mathrm{Eu}$ or $\mathrm{Tb})$ complexes also present high quantum yields of the $\mathrm{Ln}^{\mathrm{III}}$-centered emission upon excitation through the ligand levels. In the case of $\left[\mathrm{Tb}_{2}\left(\mathrm{~L}^{3}\right)\right]$, the quantum yield of the $\mathrm{Tb}^{\mathrm{III}}$-centered emission is particularly high $(50 \%)$. Considering that the relaxivity of $\left[\mathrm{Gd}_{2}\left(\mathrm{~L}^{3}\right)\right]$ is also substantially higher than that of $\left[\mathrm{Gd}_{2}\left(\mathrm{~L}^{1}\right)\right], \mathrm{L}^{3}$ appears to be a good candidate for the preparation of bimodal probes for MRI and optical imaging. Furthermore, taking together the results reported in this paper and the work of Merbach et al., ${ }^{[45]}$ it appears that there is a general trend of coordinatively unsaturated $\mathrm{Ln}^{\mathrm{III}}$ complexes with ligands containing two DO3A units linked by aromatic noncoordinating units to form stable aggregates in aqueous solutions. This discovery may be used for the design of new $\mathrm{Ln}^{\text {III }}$-based nanosized materials for application in different imaging modalities.

\section{Experimental section}

\section{$\underline{\text { General methods }}$}

Elemental analyses were carried out on a Carlo Erba 1108 elemental analyzer. High-resolution ESI-TOF mass spectra were recorded using a LC-Q-q-TOF Applied Biosystems QSTAR Elite spectrometer in the positive mode (Concentration ca. $10^{-4} \mathrm{M}$, Solvent: $\mathrm{MeOH} / \mathrm{CH}_{3} \mathrm{CN} / \mathrm{H}_{2} \mathrm{O}$ 9:1:1), or a microQTOF-Q Bruker Daltonics spectrometer in the negative mode. IR-spectra were recorded using a Bruker Vector 22 spectrophotometer equipped with a golden gate attenuated total reflectance (ATR) accessory (Specac). ${ }^{1} \mathrm{H}$ and ${ }^{13} \mathrm{C}$ NMR spectra were recorded at $25^{\circ} \mathrm{C}$ on Bruker Avance 300 and Bruker Avance $500 \mathrm{MHz}$ spectrometers. For measurements in $\mathrm{D}_{2} \mathrm{O}$, tert-butyl alcohol was used as an internal standard with the methyl signal calibrated at $\delta=1.2\left({ }^{1} \mathrm{H}\right)$ and $31.2 \mathrm{ppm}\left({ }^{13} \mathrm{C}\right)$.

\section{Absorption and emission electronic spectra}

UV/Vis absorption spectra were recorded on a Specord 205 (Analytik Jena) spectrometer. Steady state emission and excitation spectra were recorded on a Horiba Jobin Yvon Fluorolog 3 spectrometer working with a continuous $450 \mathrm{~W}$ Xe lamp. Detection was performed with a Hamamatsu R928 photomultiplier. All spectra were corrected for the instrumental functions. When necessary, a $399 \mathrm{~nm}$ cutoff filter was used to eliminate the second order artifacts. Phosphorescence lifetimes were measured on the same instrument working in the phosphorescence mode, with $50 \mu$ s delay time and a $100 \mathrm{~ms}$ integration window and fitted with the FAST program from Edinburgh Instrument. Hydrations numbers $(q)$ were obtained using Equation (1) ${ }^{[28]}$ in which $\tau_{\mathrm{H}_{2} \mathrm{O}}$ and $\tau_{\mathrm{D}_{2} \mathrm{O}}$ refer to the measured luminescence decay lifetimes (in ms) in water and deuterated water, respectively, using $A_{\mathrm{Eu}}=1.2$ and $a_{\mathrm{Eu}}=0.25$ for $\mathrm{Eu}^{\mathrm{III}}$ and $A_{\mathrm{Tb}}=5.0$ and $a_{\mathrm{Tb}}=0.06$ for $\mathrm{Tb}^{\mathrm{III}}$ : 


$$
q=A_{\mathrm{Ln}}\left(1 / \tau_{\mathrm{H}_{2} \mathrm{O}}-1 / \tau_{\mathrm{D}_{2} \mathrm{O}}-a_{\mathrm{Ln}}\right)
$$

Luminescence quantum yields were measured according to conventional procedures, ${ }^{[50]}$ with diluted solutions (optical density $<0.05$ ), using $\left[\mathrm{Ru}(\mathrm{bpy})_{3}\right] \mathrm{Cl}_{2}$ in nondegassed water $(\Phi=4.0 \%),{ }^{[29]}$ rhodamine $6 \mathrm{G}$ in water $(\Phi=76.0 \%)^{[30]}$ as references. Estimated errors are $\pm 15 \%$.

\section{$\underline{\text { Water proton relaxivity measurements }}$}

The water proton longitudinal relaxation rates as a function of temperature $(20 \mathrm{MHz})$ were measured with a Stelar Spinmaster Spectrometer (Mede, Pv, Italy) on about 0.8-2.0 mM aqueous solutions in nondeuterated water. The exact concentrations of gadolinium were determined by measurement of bulk magnetic suceptibility shifts of a $t \mathrm{BuOH}$ signal on a Bruker Avance III 500 spectrometer $(11.7 \mathrm{~T}) .{ }^{[51]}$ The ${ }^{1} \mathrm{H} T_{1}$ relaxation times were acquired by the standard inversion recovery method with typical $90^{\circ}$ pulse width of 3.5 $\mu \mathrm{s}, 16$ experiments of 4 scans. The reproducibility of the $T_{1}$ data was $\pm 5 \%$. The temperature was controlled with a Stelar VTC-91 airflow heater equipped with a calibrated copper-constantan thermocouple (uncertainty of $\pm 0.1^{\circ} \mathrm{C}$ ). The proton $1 / T_{1}$ NMRD profiles were measured on a fast field-cycling Stelar SmartTracer relaxometer over a continuum of magnetic field strengths from 0.00024 to $0.25 \mathrm{~T}$ (corresponding to $0.01-10$ $\mathrm{MHz}$ proton Larmor frequencies). The relaxometer operates under computer control with an absolute uncertainty in $1 / T_{1}$ of $\pm 1 \%$. Additional data points in the range $15-70 \mathrm{MHz}$ were obtained using a Stelar Relaxometer Consolle connected to a Bruker WP80 NMR electromagnet adapted to variable-field measurements.

\section{$\underline{{ }^{17} \mathrm{O} \text { NMR measurements }}$}

Variable-temperature ${ }^{17} \mathrm{O}-\mathrm{NMR}$ measurements were recorded on the Bruker Avance III 500 spectrometer $(11.7 \mathrm{~T})$, equipped with a $5 \mathrm{~mm}$ probe. Experimental settings: spectral width $13000 \mathrm{~Hz}, 90^{\circ}$ pulse $(18 \mu \mathrm{s})$, acquisition time $600 \mathrm{~ms}, 256 \mathrm{scans}$, and no sample spinning. Aqueous solutions of the complex (ca. $20 \mathrm{mM}$ ) containing $2.0 \%$ of the ${ }^{17} \mathrm{O}$ isotope (Cambridge Isotope) were used. The observed transverse relaxation rates $\left(R_{2}\right)$ were calculated from the signal width at half-height. The bulk magnetic susceptibility contribution was subtracted from the ${ }^{17} \mathrm{O}$ NMR shift data using the ${ }^{1} \mathrm{H}$ NMR shifts of the $t \mathrm{BuOH}$ signal as internal reference.

\section{Dynamic light scattering (DLS)}

The assessment of size and size distribution for the aggregated complexes were analyzed by Malvern Zeta Sizer Nanoinstrument (NanoZS, Malvern, UK). The Zetasizer software extracts the decay rate of the autocorrelation function by means of the routinely cumulant analysis. At the end of the analysis, the instrument gives the results in terms of sizes distribution as defined by the Stokes-Einstein equation. The wavelength of the laser light $(\mathrm{He} / \mathrm{Ne})$ was $633 \mathrm{~nm}$. The mean aggregate size diameter $(z$-average) and the polydispersity index (PDI) were issued from scattered light intensity results. Each measurement was performed in triplicate at $298 \mathrm{~K}$ and both the aggregate $z$-average diameter and PDI were determined.

\section{$\underline{\text { Transmission electron microscopy (TEM) }}$}

The sizes of the nanosized aggregates were examined by transmission electron microscopy (TEM). The samples were prepared by placing drops of the a solution containing the aggregates on a Formvar coated copper grid (Electron Microscopy Sciences, 200 mesh), followed by drying in air. The TEM images were obtained with a Jeol JEM 1100 instrument operating at a $80 \mathrm{kV}$ accelerating voltage. 


\section{Chemicals and starting materials}

2,6-Bis(3-bromomethyl-1-pyrazolyl)pyridine (1) ${ }^{[23]}$ and $\left[\mathrm{Gd}_{2}\left(\mathrm{~L}^{2}\right)\right] \cdot 4 \mathrm{H}_{2} \mathrm{O}^{[19]}$ were prepared according to literature methods. All other chemicals were purchased from commercial sources and used without further purification, unless otherwise stated. Neutral $\mathrm{Al}_{2} \mathrm{O}_{3}$ (Fluka, 0.05-0.15 mm) was used for preparative column chromatography.

2,6-Bis $\{3-[4,7,10$-tris(tert-butoxycarbonylmethyl)-1,4,7,10-tetraazacyclododecane-1-ylmethyl]-1H-pyrazol1 -yl $\}$ pyridine (2)

A mixture of $\mathrm{DO} 3 \mathrm{~A}(t \mathrm{BuO})_{3}(0.500 \mathrm{~g}, 0.971 \mathrm{mmol})$ and $\mathrm{Na}_{2} \mathrm{CO}_{3}(0.237 \mathrm{~g}, 2.23 \mathrm{mmol})$ in acetonitrile $(25 \mathrm{~mL})$ was stirred for $30 \mathrm{~min}$ and then 2,6-bis(3-bromomethyl-1-pyrazolyl)pyridine $(0.193 \mathrm{~g}, 0.486 \mathrm{mmol})$ and a catalytic amount of KI were added. The mixture was heated to reflux with stirring under an inert atmosphere (Ar) for a period of $24 \mathrm{~h}$, and then the excess of $\mathrm{Na}_{2} \mathrm{CO}_{3}$ was filtered off. The filtrate was concentrated to dryness and the yellow oil was extracted with a mixture of $\mathrm{H}_{2} \mathrm{O}$ and $\mathrm{CH}_{2} \mathrm{Cl}_{2}(1: 3 ; 100 \mathrm{~mL})$. The organic phase was evaporated to dryness to give an oily residue that was purified by column chromatography on $\mathrm{Al}_{2} \mathrm{O}_{3}$ with a $\mathrm{CH}_{2} \mathrm{Cl}_{2} / \mathrm{MeOH} 5 \%$ mixture as the eluent to give $0.544 \mathrm{~g}$ of 2 as a yellow foam. Yield $78 \%$; elemental analysis calcd (\%) for $\mathrm{C}_{65} \mathrm{H}_{109} \mathrm{~N}_{13} \mathrm{O}_{12} \cdot 2 \mathrm{CH}_{2} \mathrm{Cl}_{2}$ : C 56.10, H 7.94, $\mathrm{N}$ 12.69; found: $\mathrm{C} 55.92$, $\mathrm{H}$ 7.72, $\mathrm{N}, 12.47$; MS (ESI ${ }^{+}, \mathrm{MeOH} / \mathrm{CH}_{3} \mathrm{CN} / \mathrm{H}_{2} \mathrm{O}$ 9:1:1): $\mathrm{m} / z: 633\left[\mathrm{C}_{65} \mathrm{H}_{111} \mathrm{~N}_{13} \mathrm{O}_{12}\right]^{2+}$; IR (ATR): $\tilde{v}=1724(\mathrm{C}=\mathrm{O}$ ), 1606, $1589 \mathrm{~cm}^{-1}(\mathrm{C}=\mathrm{N}$ and $\mathrm{C}=\mathrm{C}) ;{ }^{1} \mathrm{H} \mathrm{NMR}\left(\mathrm{CDCl}_{3}, 500 \mathrm{MHz}, 25^{\circ} \mathrm{C}, \mathrm{TMS}\right): \delta=8.44\left(\mathrm{~d},{ }^{3} \mathrm{~J}=2.6 \mathrm{~Hz}, 2 \mathrm{H}\right.$; PzH), 7.91 (d, ${ }^{3} J=8.1 \mathrm{~Hz}, 2 \mathrm{H}$; PyH), $7.72\left(\mathrm{t},{ }^{3} J=8.1 \mathrm{~Hz}, 1 \mathrm{H}\right.$; PyH), 6.61 (d, ${ }^{3} J=2.6 \mathrm{~Hz}, 2 \mathrm{H}$; PzH), 3.66-1.75 (m, $48 \mathrm{H}$; - $\left.\mathrm{NCH}_{2}\right), 1.49-1.46$ ppm (m, $\left.54 \mathrm{H} ; t \mathrm{BuO}-\right) ;{ }^{13} \mathrm{C} \mathrm{NMR}\left(\mathrm{CDCl}_{3}, 125.8 \mathrm{MHz}, 25{ }^{\circ} \mathrm{C}, \mathrm{TMS}\right): \delta=172.9$, 172.6 (CO), $153.0(\mathrm{Pz})$, 149.7, $141.1(\mathrm{Py}), 127.9$ (Pz), 109.9 (Py), 109.0 (Pz), 82.1, 82.0, 56.3, 55.9, 51.4, 50.1, $31.8\left(-\mathrm{NCH}_{2}\right), 28.0,27.8 \mathrm{ppm}(\mathrm{BuO}-)$.

2,6-Bis $\{3-[4,7,10$-tris(carboxymethyl)-1,4,7,10-tetraazacyclododecane-1-ylmethyl]-1H-pyrazol-1yl pyridine hexatrifluoroacetate $\left(\mathrm{H}_{6} \underline{\left.\mathrm{L}^{3}\right)}\right.$

Compound 2 ( $0.544 \mathrm{~g}, 0.379 \mathrm{mmol})$ was dissolved in a 1:1 mixture of water and trifluoroacetic acid (10 mL). The mixture was heated to reflux with stirring for $24 \mathrm{~h}$ and then the solvents were removed in a rotary evaporator to give a brown oil. This was dissolved in $\mathrm{MeOH}(10 \mathrm{~mL})$ and the solvent evaporated. This process was repeated twice, and then three times with $\mathrm{CH}_{2} \mathrm{Cl}_{2}$. The oily residue was dissolved in $\mathrm{MeOH}(1$ $\mathrm{mL}$ ) and diethyl ether was added until the precipitation of a white solid was complete. The white solid was isolated by filtration and dried under vacuum to give $0.522 \mathrm{~g}$ of the desired compound. Yield $81 \%$; elemental analysis calcd (\%) for $\mathrm{C}_{41} \mathrm{H}_{61} \mathrm{~N}_{13} \mathrm{O}_{12} \cdot 6 \mathrm{CF}_{3} \mathrm{COOH} \cdot 5 \mathrm{H}_{2} \mathrm{O}$ : C 37.40, H 4.56, N 10.70; found: C 37.62, $\mathrm{H}$ 4.47, $\mathrm{N}$ 10.56; $\mathrm{MS}\left(\mathrm{ESI}^{+}, \mathrm{MeOH} / \mathrm{CH}_{3} \mathrm{CN} / \mathrm{H}_{2} \mathrm{O}\right.$ 9:1:1): $\mathrm{m} / z: 928 \quad\left[\mathrm{C}_{41} \mathrm{H}_{62} \mathrm{~N}_{13} \mathrm{O}_{12}\right]^{+}, 465$ $\left[\mathrm{C}_{41} \mathrm{H}_{63} \mathrm{~N}_{13} \mathrm{O}_{12}\right]^{2+}$; IR (ATR): $\tilde{v}=3416(\mathrm{O}-\mathrm{H}), 1673,1607,1588 \mathrm{~cm}^{-1}(\mathrm{C}=\mathrm{O}) ;{ }^{1} \mathrm{H}$ NMR $\left(\mathrm{D}_{2} \mathrm{O}, \mathrm{pD} 2.0,500\right.$ $\mathrm{MHz}, 25^{\circ} \mathrm{C}$, TMS): $\delta=8.51$ (s, $2 \mathrm{H}$; PzH), 8.02 (t, ${ }^{3} \mathrm{~J}=7.9 \mathrm{~Hz}, 1 \mathrm{H}$; PyH), 7.63 (d, ${ }^{3} \mathrm{~J}=7.9 \mathrm{~Hz}, 2 \mathrm{H} ;$ PyH), 6.74 (s, $2 \mathrm{H} ; \quad \mathrm{PzH}), \quad 4.13-3.02 \mathrm{ppm}\left(\mathrm{m}, \quad 48 \mathrm{H} ; \quad-\mathrm{NCH}_{2}\right) ;{ }^{13} \mathrm{C} \mathrm{NMR} \quad\left(\mathrm{D}_{2} \mathrm{O}, \quad \mathrm{pD} 2.0, \quad 125.8 \mathrm{MHz}, \quad 25^{\circ} \mathrm{C}\right.$, TMS): $\delta=174.7,171.8(\mathrm{CO}), 150.6,144.3(\mathrm{Py}), 132.3,112.3(\mathrm{Pz}), 111.9(\mathrm{Py}), 111.3(\mathrm{Pz}), 56.1,55.6,52.5$, $51.8,51.6,50.7,50.0 \mathrm{ppm}\left(-\mathrm{NCH}_{2}\right)$.

General procedure for the preparation of $\left[\mathrm{Ln}_{2}\left(\mathrm{~L}^{3}\right)\right] \cdot 2 \mathrm{H}_{2} \underline{\mathrm{O} \text { complexes }}$

A mixture of $\mathrm{H}_{6} \mathrm{~L}^{3} \cdot 6 \mathrm{CF}_{3} \mathrm{COOH} \cdot 5 \mathrm{H}_{2} \mathrm{O}(0.100 \mathrm{~g}, 0.059 \mathrm{mmol})$, triethylamine $(0.071 \mathrm{~g}, 0.705 \mathrm{mmol})$, and $\mathrm{Ln}(\mathrm{OTf})_{3}(0.117 \mathrm{mmol}, \mathrm{Ln}=\mathrm{La}, \mathrm{Eu}, \mathrm{Gd}, \mathrm{Tb}, \mathrm{Yb}$ or $\mathrm{Lu})$ in 2-propanol $(10 \mathrm{~mL})$ was heated to reflux for $24 \mathrm{~h}$. The reaction was allowed to cool to room temperature, resulting in the formation of a white precipitate that was washed with $\mathrm{MeOH}$ and diethyl ether. The mother liquor was stored at $4{ }^{\circ} \mathrm{C}$ for several days, resulting in the formation of a second batch of complex that was again collected by filtration and washed with $\mathrm{MeOH}$ and diethyl ether. 
[ $\left.\mathbf{L a}_{2}\left(\mathbf{L}^{3}\right)\right] \cdot 2 \mathbf{H}_{2} \mathbf{O}$ : Yield $0.064 \mathrm{~g}, 88 \%$; elemental analysis calcd (\%) for $\mathrm{C}_{41} \mathrm{H}_{55} \mathrm{La}_{2} \mathrm{~N}_{13} \mathrm{O}_{12} \cdot 2 \mathrm{H}_{2} \mathrm{O}$ : C 39.85, $\mathrm{H}$ 4.81, N 14.73; found: C 39.66, H 4.59, N 14.58; HR-MS (ESI ${ }^{+}, \mathrm{MeOH} / \mathrm{CH}_{3} \mathrm{CN}_{2} \mathrm{H}_{2} \mathrm{O}$ 9:1:1): $\mathrm{m} / z$ calcd for $\left[\mathrm{C}_{41} \mathrm{H}_{57} \mathrm{La}_{2} \mathrm{~N}_{13} \mathrm{O}_{12}\right]^{2+}: 600.6182$; found: 600.6157; IR (ATR): $\tilde{v}=1575 \mathrm{~cm}^{-1}(\mathrm{C}=\mathrm{O})$.

$\left[\mathbf{E u}_{2}\left(\mathbf{L}^{3}\right)\right] \cdot 2 \mathbf{H}_{2} \mathbf{O}$ : Yield $0.067 \mathrm{~g}, 90 \%$; elemental analysis calcd (\%) for $\mathrm{C}_{41} \mathrm{H}_{55} \mathrm{Eu}_{2} \mathrm{~N}_{13} \mathrm{O}_{12} \cdot 2 \mathrm{H}_{2} \mathrm{O}: \mathrm{C}$ 39.02, $\mathrm{H}$ 4.71, $\mathrm{N}$ 14.43; found: $\mathrm{C}$ 38.86, $\mathrm{H}$ 4.56, $\mathrm{N}$ 14.28; HR-MS $\left(\mathrm{ESI}^{+}, \mathrm{MeOH} / \mathrm{CH}_{3} \mathrm{CN} / \mathrm{H}_{2} \mathrm{O}\right.$ 9:1:1): $\mathrm{m} / \mathrm{z}$ calcd for $\left[\mathrm{C}_{41} \mathrm{H}_{57} \mathrm{Eu}_{2} \mathrm{~N}_{13} \mathrm{O}_{12}\right]^{2+}$ : 614.6331; found: 614.6354; m/z calcd for $\left[\mathrm{C}_{41} \mathrm{H}_{56} \mathrm{Eu}_{2} \mathrm{~N}_{13} \mathrm{O}_{12}\right]^{+} 1228.2590$; found: 1228.2586; IR (ATR): $\tilde{v}=1583 \mathrm{~cm}^{-1}(\mathrm{C}=\mathrm{O})$.

$\left[\mathbf{G d}_{2}\left(\mathbf{L}^{3}\right)\right] \cdot 2 \mathrm{H}_{2} \mathrm{O}$ : Yield $0.068 \mathrm{~g}, 91 \%$; elemental analysis calcd (\%) for $\mathrm{C}_{41} \mathrm{H}_{55} \mathrm{Gd}_{2} \mathrm{~N}_{13} \mathrm{O}_{12} \cdot 2 \mathrm{H}_{2} \mathrm{O}: \mathrm{C} 38.70, \mathrm{H}$ 4.67, N 14.31; found: C 38.87, H 4.91, N 14.38; HR-MS (ESI ${ }^{+}, \mathrm{MeOH} / \mathrm{CH}_{3} \mathrm{CN} / \mathrm{H}_{2} \mathrm{O}$ 9:1:1): $\mathrm{m} / z$ calcd for $\left[\mathrm{C}_{41} \mathrm{H}_{57} \mathrm{Gd}_{2} \mathrm{~N}_{13} \mathrm{O}_{12}\right]^{2+}: 619.6360$; found: $619.6380 ; \mathrm{m} / z$ calcd for $\left[\mathrm{C}_{41} \mathrm{H}_{55} \mathrm{Gd}_{2} \mathrm{~N}_{13} \mathrm{NaO}_{12}\right]^{+}:$1260.2467; found: 1260.2487; IR (ATR): $\tilde{v}=1583 \mathrm{~cm}^{-1}(\mathrm{C}=\mathrm{O})$.

$\left[\mathbf{T b}_{2}\left(\mathbf{L}^{3}\right)\right] \cdot 2 \mathbf{H}_{2} \mathbf{O}$ : Yield $0.067 \mathrm{~g}, 89 \%$; elemental analysis calcd (\%) for $\mathrm{C}_{41} \mathrm{H}_{55} \mathrm{~N}_{13} \mathrm{O}_{12} \mathrm{~Tb}_{2} \cdot 2 \mathrm{H}_{2} \mathrm{O}: \mathbf{C} 38.60, \mathrm{H}$ 4.66, N 14.27; found: $\mathrm{C} 38.49, \mathrm{H}$ 4.83, $\mathrm{N}$ 14.32; HR-MS (ESI ${ }^{+}, \mathrm{MeOH} / \mathrm{CH}_{3} \mathrm{CN} / \mathrm{H}_{2} \mathrm{O}$ 9:1:1): $\mathrm{m} / z$ calcd for $\left[\mathrm{C}_{41} \mathrm{H}_{57} \mathrm{~N}_{13} \mathrm{O}_{12} \mathrm{~Tb}_{2}\right]^{2+}: 620.6372$; found: $620.6400 ; \mathrm{m} / z$ calcd for $\left[\mathrm{C}_{41} \mathrm{H}_{56} \mathrm{~N}_{13} \mathrm{O}_{12} \mathrm{~Tb}_{2}\right]^{+}:$1240.2672; found: 1240.2634; IR (ATR): $\tilde{v}=1584 \mathrm{~cm}^{-1}(\mathrm{C}=\mathrm{O})$.

[ $\left.\mathbf{Y b}_{\mathbf{2}}\left(\mathbf{L}^{\mathbf{3}}\right)\right] \cdot \mathbf{2} \mathbf{H}_{2} \mathbf{O}$ : Yield $0.067 \mathrm{~g}, 87 \%$; elemental analysis calcd (\%) for $\mathrm{C}_{41} \mathrm{H}_{55} \mathrm{~N}_{13} \mathrm{O}_{12} \mathrm{Yb}_{2} \cdot 2 \mathrm{H}_{2} \mathrm{O}: \mathrm{C} 37.76, \mathrm{H}$ 4.56, N 13.96; found: C 38.02, H 4.73, N 13.72, HR-MS (ESI ${ }^{+}, \mathrm{MeOH} / \mathrm{CH}_{3} \mathrm{CN}_{2} \mathrm{H}_{2} \mathrm{O}$ 9:1:1): $\mathrm{m} / z$ calcd for $\left[\mathrm{C}_{41} \mathrm{H}_{55} \mathrm{~N}_{13} \mathrm{Na}_{2} \mathrm{O}_{12} \mathrm{Yb}_{2}\right]^{2+}$ : 657.6327; found: $657.6343 ; \mathrm{m} / z$ calcd for $\left[\mathrm{C}_{41} \mathrm{H}_{55} \mathrm{~N}_{13} \mathrm{NaO}_{12} \mathrm{Yb}_{2}\right]^{+}:$1292.2762; found: 1292.2719; IR (ATR): $\tilde{v}=1585 \mathrm{~cm}^{-1}(\mathrm{C}=\mathrm{O})$.

$\left[\mathbf{L u}_{2}\left(\mathbf{L}^{3}\right)\right] \cdot 2 \mathbf{H}_{2} \mathbf{O}$ : Yield $0.068 \mathrm{~g}, 88 \%$. elemental analysis calcd (\%) for $\mathrm{C}_{41} \mathrm{H}_{55} \mathrm{Lu}_{2} \mathrm{~N}_{13} \mathrm{O}_{12} \cdot 2 \mathrm{H}_{2} \mathrm{O}: \mathrm{C} 37.65, \mathrm{H}$ 4.55, N 13.92; found: C 37.52, $\mathrm{H}$ 4.76, $\mathrm{N}$ 13.75; HS-MS (ESI ${ }^{+}, \mathrm{MeOH} / \mathrm{CH}_{3} \mathrm{CN} / \mathrm{H}_{2} \mathrm{O}$ 9:1:1): $\mathrm{m} / z$ calcd for $\left[\mathrm{C}_{41} \mathrm{H}_{57} \mathrm{Lu}_{2} \mathrm{~N}_{13} \mathrm{O}_{12}\right]^{2+}:$ 636.6527; found: $636.6547 ; \mathrm{m} / z$ calcd for $\left[\mathrm{C}_{41} \mathrm{H}_{56} \mathrm{Lu}_{2} \mathrm{~N}_{13} \mathrm{O}_{12}\right]^{+}:$: 272.2981 ; found: 1272.2937; IR (ATR): $\tilde{v}=1587 \mathrm{~cm}^{-1}(\mathrm{C}=\mathrm{O}) ;{ }^{1} \mathrm{H}$ NMR $\left(\mathrm{D}_{2} \mathrm{O}, \mathrm{pD} 7.0,500 \mathrm{MHz}, 25^{\circ} \mathrm{C}, \mathrm{TMS}\right): \delta=8.53$ (m, $2 \mathrm{H}), 8.13(\mathrm{~m}, 1 \mathrm{H}), 7.61(\mathrm{~m}, 2 \mathrm{H}), 6.64(\mathrm{~m}, 2 \mathrm{H}), 4.31-2.60 \mathrm{ppm}(\mathrm{m}, 48 \mathrm{H}) ;{ }^{13} \mathrm{C}$ NMR $\left(\mathrm{D}_{2} \mathrm{O}, \mathrm{pD} 7.0,125.8\right.$ $\mathrm{MHz}, 25^{\circ} \mathrm{C}$, TMS): $\delta=182.7,182.1,181.1,156.1,150.7,144.5,136.6,116.1,110.4,67.8,67.0,61.7,60.8$, $57.7,57.0,56.7,55.8,54.8,53.5,51.8,50.0 \mathrm{ppm}$.

[ $\left.\mathbf{G d}_{2}\left(\mathbf{L}^{1}\right)\right] \cdot 6 \mathrm{H}_{2} \mathbf{O}$ : A mixture of $\mathrm{H}_{6} \mathrm{~L}^{1} \cdot 6 \mathrm{CF}_{3} \mathrm{COOH} \cdot 3 \mathrm{H}_{2} \mathrm{O}^{[20]}(0.100 \mathrm{~g}, 0.062 \mathrm{mmol})$, triethylamine $(0.075 \mathrm{~g}$, $0.744 \mathrm{mmol})$, and $\mathrm{Gd}(\mathrm{OTf})_{3}(0.075 \mathrm{~g}, 0.124 \mathrm{mmol})$ in 2-propanol $(10 \mathrm{~mL})$ was heated to reflux for $24 \mathrm{~h}$. The reaction was allowed to cool to room temperature, resulting in the formation of a white precipitate that was washed with $\mathrm{MeOH}$ and diethyl ether. The mother liquor was stored at $4{ }^{\circ} \mathrm{C}$ for several days, resulting in the formation of a second batch of complex that was again collected by filtration and washed with $\mathrm{MeOH}$ and diethyl ether. Yield $0.062 \mathrm{~g}, 77 \%$; elemental analysis calcd (\%) for $\mathrm{C}_{40} \mathrm{H}_{54} \mathrm{Gd}_{2} \mathrm{~N}_{10} \mathrm{O}_{12} \cdot 6 \mathrm{H}_{2} \mathrm{O}$ : C 37.26, $\mathrm{H}$ 5.16, N 10.86; found: C 37.01, H 4.91, N 10.78; HS-MS (ESI ${ }^{+}, \mathrm{MeOH} / \mathrm{CH}_{3} \mathrm{CN}_{2} / \mathrm{H}_{2} \mathrm{O}$ 9:1:1): $\mathrm{m} / z$ calcd for $\left[\mathrm{C}_{40} \mathrm{H}_{56} \mathrm{Gd}_{2} \mathrm{~N}_{10} \mathrm{O}_{12}\right]^{2+}$ : 592.1275; found: 592.1298; IR (ATR): $\tilde{v}=1581 \mathrm{~cm}^{-1}(\mathrm{C}=\mathrm{O})$.

\section{Computational methods}

All calculations were performed employing the Gaussian 09 package (Revision A.02) ${ }^{[52]}$ Full geometry optimizations of the $\left[\mathrm{Gd}_{2}\left(\mathrm{~L}^{3}\right)\left(\mathrm{H}_{2} \mathrm{O}\right)_{2}\right]$ systems were performed at the HF level by using the effective core potential (ECP) of Dolg et al., ${ }^{[53]}$ the related [5s4p3d]-GTO valence basis set for the lanthanides, ${ }^{[53]}$ and the 3-21G basis set for $\mathrm{C}, \mathrm{H}, \mathrm{N}$, and $\mathrm{O}$ atoms. Although small, HF calculations employing this basis set in combination with the $f$-in-core ECP of Dolg were shown to provide molecular geometries of $\mathrm{Ln}^{\mathrm{III}}$-dota-like complexes in good agreement with the experimental structures observed by single-crystal X-ray diffraction studies. ${ }^{[54]}$ No symmetry constraints were imposed during the optimizations. The stationary points found on the potential energy surfaces as a result of the geometry optimizations were tested to represent energy 
minima rather than saddle points by means of a frequency analysis. The relative free energies of the different conformations obtained from geometry optimizations were calculated at the same computational level, and they include nonpotential-energy contributions (zero point energies and thermal terms) obtained through frequency analysis. Selected geometries optimized at the HF level were subsequently fully optimized by using hybrid DFT with the B3LYP exchange-correlation functional, ${ }^{[5]}$ and the standard $6-31 \mathrm{G}(\mathrm{d})$ basis set for the ligand atoms. Due to the considerable computational effort involving the calculation of second derivatives at this level the optimized geometries were not characterized by using frequency analysis. Molecular volumes, defined as the volume inside a contour of $0.001 \mathrm{e} \mathrm{Bohr}^{-3}$, were calculated at the B3LYP/6-31G(d) level by using the volume=tight keyword in Gaussian 09.

\section{Acknowledgements}

M. R.-F., D. E.-G., A. de B., T. R.-B. and C. P.-I. thank Ministerio de Educación y Ciencia (MEC, CTQ2009-10721), Fondo Europeo de Desarrollo Regional (FEDER, CTQ2009-10721) and Xunta de Galicia (IN845B-2010/063) for financial support. This research was performed in the frameworks of the EU COST Actions D38 "Metal-Based Systems for Molecular Imaging Applications" and CM1006 "EUFEN: European F-Element Network". The authors are indebted to Centro de Supercomputación de Galicia (CESGA) for providing the computer facilities. A.N. and L.J.C. gratefully acknowledge the financial support of the French Centre National de la Recherche Scientifique, the University of Strasbourg and the European Commission (NANOGNOSTICS, n $^{\circ}$ 22264). M.B. and G.R. are grateful to MIUR (PRIN 2009) for financial support. M.R.-F. also thanks the Ministerio de Educación y Ciencia (FPU program) for a predoctoral fellowship.

\section{References}

[1] a) C. M. G. dos Santos, A. J. Harte, S. J. Quinn, T. Gunnlaugsson, Coord. Chem. Rev. 2008, 252, 25122527; b) L. S. Natrajan, Current Inorg. Chem. 2011, 1, 61-75; c) E. Brunet, O. Huanes, J. C. RodriguezUbis, Current Chem. Biol. 2007, 1, 11-39; d) L. J. Charbonnière, Current Inorg. Chem. 2011, 1, 2-16; e) J. Xu, T. M. Corneillie, E. G. Moore, G.-L. Law, N. G. Butlin, K. N. Raymond, J. Am. Chem. Soc.2011, 133, 19900-19910.

[2] The Chemistry of Contrast Agents in Medical Magnetic Resonance Imaging (Eds.: A. E. Merbach, L. Helm E. Toth), 2nd ed., Wiley, New York, 2013.

[3] a) P. Caravan, J. J. Ellinson, T. J. McMurry, R. B. Lauffer, Chem. Rev. 1999, 99, 2293-2352; b) K. W.Y. Chan, W.-T. Wong, Coord. Chem. Rev. 2007, 251, 2428-2451; c) E. Terreno, D. Delli Castelli, A. Viale, S. Aime, Chem. Rev. 2010, 110, 3019-3042; d) A. Datta, K. N. Raymond, Acc. Chem. Res. 2009, 42, 938947.

[4] S. Cheng, L. Abramova, G. Saab, G. Turabelidze, P. Patel, M. Arduino, T. Hess, A. Kallen, M. Jhung, JAMA J. Am. Med. Assoc. 2007, 297, 1542-1544.

[5] "Stability and Toxicity of Contrast Agents": E. Brücher, A. D. Sherry, in The Chemistry of Contrast Agents in Medical Magnetic Resonante Imaging (Eds.: A. E. Merbach, É. Tóth), Wiley, Chichester, 2001, pp. 243-279.

[6] a) B. Alpha, J.-M. Lehn, G. Mathis, Angew. Chem. 1987, 99, 259-261; Angew. Chem. Int. Ed. Engl. 1987, 26, 266-267; b) B. Alpha, R. Ballardi, V. Balzani, J.-M. Lehn, S. Perathoner, N. Sabbatini, Photochem. Photobiol.1990, 52, 299-306. 
[7] R. Uppal, K. L. Ciesienski, D. B. Chonde, G. S. Loving, P. Caravan, J. Am. Chem. Soc. 2012, 134, 10799-10802.

[8] M. Sun, D. Hoffman, G. Sundaresan, L. Yang, N. Lamichhane, J. Zweit, Am. J. Nucl. Med. Mol. Imaging 2012, 2, 122-135.

[9] a) A. Keliris, T. Ziegler, R. Mishra, R. Pohmann, M. G. Sauer, K. Ugurbil, J. Engelmann, Bioorg. Med. Chem. 2011, 19, 2529-2540; b) A. B. Bourlinos, A. Bakandritsos, A. Kouloumpis, D. Gournis, M. Krysmann, E. P. Giannelis, K. Polakova, K. Safarova, K. Hola, R. Zboril, J. Mater. Chem. 2012, 22, 23327 23330; c) H. Yang, L. Ding, L. An, Z. Xiang, M. Chen, J. Zhou, F. Li, D. Wu, S. Yang, Biomaterials 2012, 33, 8591-8599; d) D. Dong, X. Jing, X. Zhang, X. Hu, Y. Wu, C. Duan, Tetrahedron 2012, 68, 306310; e) S. Claudel-Gillet, J. Steibel, N. Weibel, T. Chauvin, M. Port, I. Raynal, E. Toth, R. Ziessel, L. J. Charbonnière, Eur. J. Inorg. Chem. 2008, 2856-2862; f) A. Nonat, C. Gateau, P. H. Fries, L. Helm, M. Mazzanti, Eur. J. Inorg. Chem. 2012, 2049-2061.

[10] M. Latva, H. Takalo, V.-M. Mukkala, C. Matachescu, J. C. Rodriguez-Ubis, J. Kankare, J. Lumin 1997, $75,149-169$.

[11] W. D. Horrocks, Jr., D. R. Sudnick, J. Am. Chem. Soc. 1979, 101, 334-340.

[12] E. Pérez-Mayoral, V. Negri, J. Soler-Padros, S. Cerdan, P. Ballesteros, Eur. J. Radiol. 2008, 67, 453458.

[13] G. Angelovski, I. Mamedov, Current Inorg. Chem. 2011, 1, 76-90.

[14] a) E. J. Werner, A. Datta, C. J. Jocher, K. N. Raymond, Angew. Chem. 2008, 120, 8696-8709; Angew. Chem. Int. Ed. 2008, 47, 8568-8580; b) S. Aime, M. Botta, E. Terreno, Adv. Inorg. Chem. 2005, 57, 173237.

[15] a) G. Tallec, P. H. Fries, D. Imbert, M. Mazzanti, Inorg. Chem. 2011, 50, 7943-7945; b) G. Tallec, D. Imbert, P. H. Fries, M. Mazzanti, Dalton Trans. 2010, 39, 9490-9492; c) F. Caillé, C. S. Bonnet, F. Buron, S. Villette, L. Helm, S. Petoud, F. Suzenet, É. Tóth, Inorg. Chem. 2012, 51, 2522-2532; d) C. S. Bonnet, F. Buron, F. Caillé, C. M. Shade, B. Drahos, L. Pellegatti, J. Zhang, S. Villette, L. Helm, C. Pichon, F. Suzenet, S. Petoud, É. Tóth, Chem. Eur. J. 2012, 18, 1419-1431; e) G. Dehaen, S. V. Eliseeva, K. Kimpe, S. Laurent, L. Vander Elst, R. N. Muller, W. Dehaen, K. Binnemans, T. N. Parac-Vogt, Chem. Eur. J. 2012, 18, 293302; f) M. P. Placidi, J. Engelmann, L. S. Natrajan, N. K. Logothetis, G. Angelovski, Chem. Commun. 2011, 47, 11534-11536; g) C. S. Bonnet, É. Tóth, C. R. Chim. 2010, 13, 700-714; h) S. Laurent, L. Vander Elst, M. Wautier, C. Galaup, R. N. Muller, C. Picard, Bioorg. Med. Chem. Lett. 2007, 17, 6230-6233.

[16] L. Pellegatti, J. Zhang, B. Drahos, S. Villette, F. Suzenet, G. Guillaumet, S. Petoud, É. Tóth, Chem. Commun. 2008, 6591-6593.

[17] a) W.-S. Li, J. Luo, F. Jiang, Z.-N. Chen, Dalton Trans. 2012, 41, 9405-9410; b) J. E. Jones, A. J. Amoroso, I. M. Dorin, G. Parigi, B. D. Ward, N. J. Buurma, S. J. Pope, Chem. Commun. 2011, 47, 33743376.

[18] a) L. Frullano, T. J. Meade, J. Biol. Inorg. Chem. 2007, 12, 939-949; b) F. Lux, S. Roux, P. Perriat, O. Tillement, Curr. Inorg. Chem. 2011, 1, 117-129.

[19] A. Nonat, M. Regueiro-Figueroa, D. Esteban-Gomez, A. de Blas, T. Rodriguez-Blas, C. Platas-Iglesias, L. J. Charbonnière, Chem. Eur. J. 2012, 18, 8163-8173. 
[20] L. J. Charbonnière, S. Faulkner, C. Platas-Iglesias, M. Regueiro-Figueroa, A. Nonat, T. Rodríguez-Blas, A. de Blas, W. S. Perry, M. Tropiano, Dalton Trans. 2013, 42, 3667-3681.

[21] a) M. Mato-Iglesias, T. Rodriguez-Blas, C. Platas-Iglesias, M. Starck, P. Kadjane, R. Ziessel, L. J. Charbonnière, Inorg. Chem. 2009, 48, 1507-1518; b) N. N. Katia, A. Lecointre, M. Regueiro-Figueroa, C. Platas-Iglesias, L. J. Charbonnière, Inorg. Chem. 2011, 50, 1689-1697.

[22] a) E. Brunet, O. Juanes, R. Sedano, J.-C. Rodriguez-Ubis, Photochem. Photobiol. Sci. 2002, 1, 613-618; b) M. J. Remuinan, H. Roman, M. T. Alonso, J. C. Rodriguez-Ubis, J. Chem. Soc. Perkin Trans. 2 1993, 1099-1102.

[23] M. Starck, P. Kadjane, E. Bois, B. Darbouret, A. Incamps, R. Ziessel, L. J. Charbonnière, Chem. Eur. J. 2011, 17, 9164-9179.

[24] A. Barge, L. Tei, D. Upadhyaya, F. Fedeli, L. Beltrami, R. Stefania, S. Aime, G. Cravotto, Org. Biomol. Chem. 2008, 6, 1176-1184.

[25] M. Regueiro-Figueroa, D. Esteban-Gomez, A. de Blas, T. Rodriguez-Blas, C. Platas-Iglesias, Eur. J. Inorg. Chem. 2010, 3586-3595.

[26] a) L. S. Natrajan, A. J. L. Villaraza, A. M. Kenwright, S. Faulkner, Chem. Commun. 2009, 6020-6022; b) M. Main, M. M. Meloni, M. Jauregui, D. Sykes, S. Faulkner, A. M. Kenwright, J. S. Snaith, Chem. Commun. 2008, 5212-5214.

[27] J.-C. G. Bünzli, Chem. Rev. 2010, 110, 2729-2755.

[28] A. Beeby, I. M. Clarkson, R. S. Dickins, S. Faulkner, D. Parker, L. Royle, A. S. de Sousa, J. A. G. Williams, M. Woods, J. Chem. Soc. Perkin Trans. 2 1999, 493-503.

[29] H. Ishida, S. Tobita, Y. Hasegawa, R. Katoh, K. Noaki, Coord. Chem. Rev. 2010, 254, 2449-2458.

[30] J. Olmsted III, J. Phys. Chem. 1979, 83, 2581-2584.

[31] M. Botta, S. Aime, A. Barge, G. Bobba, R. S. Dickins, D. Parker, E. Terreno, Chem. Eur. J. 2003, 9 , 2102-2109.

[32] S. Aime, M. Botta, S. G. Crich, G. Giovenzana, R. Pagliarin, M. Sisti, E. Terreno, Magn. Reson. Chem. 1998, 36, S200-S208.

[33] a) N. Bloembergen, J. Chem. Phys. 1957, 27, 572-573; b) I. Solomon, Phys. Rev. 1955, 99, 559-565; c) N. Bloembergen, L. O. Morgan, J. Chem. Phys. 1961, 34, 842-850.

[34] J. H. Freed, J. Chem. Phys. 1978, 68, 4034-4037.

[35] A. Roca-Sabio, C. S. Bonet, M. Mato-Iglesias, D. Esteban-Gomez, E. Toth, A. de Blas, T. RodriguezBlas, C. Platas-Iglesias, Inorg. Chem. 2012, 51, 10893-10903.

[36] D. H. Powell, O. M. Ni Dhubhghaill, D. Purbanz, L. Helm, Y. S. Lebedev, W. Schlaepfer, A. E. Merbach, J. Am. Chem. Soc. 1996, 118, 9333-9346.

[37] D. Esteban-Gómez, A. de Blas, T. Rodriguez-Blas, L. Helm, C. Platas-Iglesias, ChemPhysChem 2012, 13, 3640-3650. 
[38] a) A. Mishra, P. Fouskova, G. Angelovski, E. Balogh, A. K. Mishra, N. K. Logothetis, E. Toth, Inorg. Chem. 2008, 47, 1370-1381; b) J. Costa, E. Toth, L. Helm, A. E. Merbach, Inorg. Chem. 2005, 44, 47474755 .

[39] W.-H. Li, G. Parigi, M. Fragai, C. Luchinat, T. J. Meade, Inorg. Chem. 2002, 41, 4018-4024.

[40] E. Tóth, O. M. Ni Dhubhghaill, G. Besson, L. Helm, A. E. Merbach, Magn. Reson. Chem. 1999, 37, 701-708.

[41] a) S. Laus, R. Ruloff, E. Toth, A. E. Merbach, Chem. Eur. J. 2003, 9, 3555-3566; b) J. Kotek, P. Lebduskova, P. Hermann, L. Vander Elst, R. N. Muller, C. F. G. C. Geraldes, T. Maschmeyer, I. Lukes, J. A. Peters, Chem. Eur. J. 2003, 9, 5899-5915; c) E. Balogh, M. Mato-Iglesias, C. Platas-Iglesias, E. Toth, K. Djanashvili, J. A. Peters, A. de Blas, T. Rodriguez-Blas, Inorg. Chem. 2006, 45, 8719-8728.

[42] P. Caravan, C. T. Farrar, L. Frullano, R. Uppal, Contrast Media Mol. Imaging 2009, 4, 89-100.

[43] a) P. Caravan, Chem. Soc. Rev. 2006, 35, 512-523; b) M. Botta, L. Tei, Eur. J. Inorg. Chem. 2012, 1945-1960.

[44] a) N. J. J. Johnson, W. Oakden, G. J. Stanisz, R. S. Prosser, F. C. J. M. van Veggel, Chem. Mater. 2011, 23, 3714-3722; b) F. Carniato, K. Thangavel, L. Tei, M. Botta, J. Mater. Chem. B 2013, 1, 2442-2446.

[45] J. Costa, E. Balogh, V. Turcry, R. Tripier, M. Le Baccon, F. Chuburu, H. Handel, L. Helm, E. Toth, A. E. Merbach, Chem. Eur. J. 2006, 12, 6841-6851.

[46] N. Fatin-Rouge, E. Toth, D. Perret, R. H. Backer, A. E. Merbach, J.-C. G. Bunzli, J. Am. Chem. Soc. 2000, 122, 10810-10820.

[47] a) M. B. Inoue, M. Inoue, Q. Fernando, Inorg. Chim. Acta 1995, 232, 203-206; b) S. I. Kang, R. S. Ranganathan, J. E. Emswiler, K. Kumar, J. Z. Gougoutas, M. F. Malley, M. F. Tweedle, Inorg. Chem. 1993, 32, 2912-2918.

[48] M. Mato-Iglesias, A. Roca-Sabio, Z. Palinkas, D. Esteban-Gomez, C. Platas-Iglesias, E. Toth, A. de Blas, T. Rodriguez-Blas, Inorg. Chem. 2008, 47, 7840-7851.

[49] M. Jauregui, W. S. Perry, C. Allain, L. R. Vidler, M. C. Willis, A. M. Kenwright, J. S. Snaith, G. J. Stasiuk, M. P. Lowe, S. Faulkner, Dalton Trans. 2009, 6283-6285.

[50] G. A. Crosby, J. N. Demas, J. Phys. Chem. 1971, 75, 991-1024.

[51] D. M. Corsi, C. Platas-Iglesias, H. van Bekkum, J. A. Peters, Magn. Reson. Chem. 2001, 39, 723-726.

[52] Gaussian 09, Revision A.02, M. J. Frisch, G. W. Trucks, H. B. Schlegel, G. E. Scuseria, M. A. Robb, J. R. Cheeseman, G. Scalmani, V. Barone, B. Mennucci, G. A. Petersson, H. Nakatsuji, M. Caricato, X. Li, H. P. Hratchian, A. F. Izmaylov, J. Bloino, G. Zheng, J. L. Sonnenberg, M. Hada, M. Ehara, K. Toyota, R. Fukuda, J. Hasegawa, M. Ishida, T. Nakajima, Y. Honda, O. Kitao, H. Nakai, T. Vreven, J. A. Montgomery, Jr., J. E. Peralta, F. Ogliaro, M. Bearpark, J. J. Heyd, E. Brothers, K. N. Kudin, V. N. Staroverov, R. Kobayashi, J. Normand, K. Raghavachari, A. Rendell, J. C. Burant, S. S. Iyengar, J. Tomasi, M. Cossi, N. Rega, J. M. Millam, M. Klene, J. E. Knox, J. B. Cross, V. Bakken, C. Adamo, J. Jaramillo, R. Gomperts, R. E. Stratmann, O. Yazyev, A. J. Austin, R. Cammi, C. Pomelli, J. W. Ochterski, R. L. Martin, K. Morokuma, V. G. Zakrzewski, G. A. Voth, P. Salvador, J. J. Dannenberg, S. Dapprich, A. D. Daniels, Ö. Farkas, J. B. Foresman, J. V. Ortiz, J. Cioslowski, D. J. Fox, Gaussian, Inc. Wallingford CT, 2009.

[53] M. Dolg, H. Stoll, A. Savin, H. Preuss, Theor. Chim. Acta 1989, 75, 173-194. 
[54] U. Cosentino, A. Villa, D. Pitea, G. Moro, V. Barone, A. Maiocchi, J. Am. Chem. Soc. 2002, 124, 49014909.

[55] a) A. D. Becke, J. Chem. Phys. 1993, 98, 5648-5652; b) C. Lee, W. Yang, R. G. Parr, Phys. Rev. $B$ 1988, 37, 785-789.

\footnotetext{
${ }^{\mathrm{i}}$ Supporting information for this article is available online: https://doi.org/10.1002/chem.201301231.
} 